\title{
Sensitivity of Arctic Climate Variability to Mean State: Insights from the Cretaceous
}

\author{
CHRISTOPHER J. POULSEN \\ Department of Earth and Environmental Sciences, University of Michigan, Ann Arbor, Michigan \\ JING ZHOU \\ Department of Earth and Environmental Sciences, University of Michigan, Ann Arbor, Michigan, \\ and Earth Sciences Division, Lawrence Berkeley National Laboratory, Berkeley, California
}

(Manuscript received 19 November 2012, in final form 6 March 2013)

\begin{abstract}
This study investigates Arctic climate variability during a period of extreme warmth using the Community Climate System Model, version 3 (CCSM3) coupled ocean-atmosphere general circulation model. Four midCretaceous simulations were completed with different $\mathrm{CO}_{2}$ levels $(1,10$, and 16 times preindustrial levels with dynamic vegetation) and vegetation treatments (10 times with specified uniform bare ground). The magnitude and frequency of Arctic temperature variability is highly sensitive to the mean state and high-latitude upperocean static stability. As stability increases with a rise in $\mathrm{CO}_{2}$ levels from 1 to 10 times preindustrial levels, the frequency of temperature variability increases from decades $(1 \mathrm{x})$ to centuries (10x with bare ground) and longer (10x) and the peak-to-peak magnitude increases from $\sim 1^{\circ}$ (for $1 \mathrm{x}$ ) to $\sim 2^{\circ} \mathrm{C}$ (for $10 \mathrm{x}$ ). In the $16 \mathrm{x}$ simulation with a highly stratified ocean, Arctic temperature variability is low with peak-to-peak magnitudes $<0.5^{\circ} \mathrm{C}$. Under low $\mathrm{CO}_{2}$, Arctic climate variability is tied to sensible heat release from the ocean during movement of the sea ice margin. In absence of substantial sea ice, variability is driven by mass transport and upper-ocean salinity advection into the Arctic. In both cases, destruction of low-level clouds acts as an important feedback on lowlevel warming. The authors also report a link between unforced Arctic climate variability and North Pacific meridional overturning with warming events leading intensification. These results suggest that the nature of Arctic climate variability was likely much different in past climates and is likely to be so in the future.
\end{abstract}

\section{Introduction}

On submillennial time scales, internal natural variability is a substantial component of Earth's climate variability. The nature (amplitude, frequency) of unforced climate variability is tied to the mean state of the climate. This conclusion is supported, for example, by modern observational evidence that El Niño events have intensified in the central Pacific as a result of climate change (Lee and McPhaden 2010), paleoclimate evidence suggesting that the magnitude and frequency of El Niño were different in the past (e.g., Sandweiss et al. 2001; Stott et al. 2002; Koutavas and Joanides 2012), and numerical models that predict shifts in the character of natural variability under greenhouse and

Corresponding author address: Christopher J. Poulsen, Dept. of Earth and Environmental Sciences, University of Michigan, 2534 C.C. Little Building, 1100 North University Avenue, Ann Arbor, MI 48109. E-mail: poulsen@umich.edu orbital forcing (e.g., Clement et al. 2001; Timmermann et al. 1999). Understanding how natural variability is modulated as a function of mean state is essential to predicting both future and past climate variability. This question is particularly relevant in the Arctic, a region that is currently undergoing rapid warming and sea ice decline (e.g., Parkinson et al. 1999; Comiso 2002) and in the distant past was seasonally ice free (e.g., Jenkyns et al. 2004).

During the last 100 years, the Arctic region $\left(70^{\circ}-90^{\circ} \mathrm{N}\right)$ has experienced decadal and multidecadal variability in surface temperature and sea ice (Vinje 2001; Polyakov 2002). Although human activities have undoubtedly contributed (Johannessen et al. 2004), internal natural variability involving ocean-atmosphere interactions is a substantial, if not primary, source of this high-frequency climate variability (Polyakov 2002; Goosse and Holland 2005). During the twentieth century, the Arctic region experienced two multidecadal warm events with annual surface temperature increases of $1.7^{\circ} \mathrm{C}$ and greater 
(Polyakov 2002; Johannessen et al. 2004). The cause of these events is not known with certainty but is thought to involve natural ocean-atmosphere variability and Arctic sea ice retreat. Analyses of Arctic climate variability in the ECHAM and the Community Climate System Model (CCSM) climate models support this conclusion. Both models exhibit Arctic warm events, similar to those observed, which are triggered by westerly wind anomalies in the North Atlantic, enhancement of upper-level warm seawater transport through the Barents Sea, and Arctic sea ice retreat (Bengtsson et al. 2004; Goosse and Holland 2005).

The character of Arctic climate variability in a warmer climate without annual sea ice cover is unknown, but is relevant to both past and future times. The Cretaceous was a past period of exceptional warmth, attributed mainly to high partial pressure of carbon dioxide (in the range of 700 and $>4000$ ppmv; Bice and Norris 2002) as a result of high background rates of volcanic degassing (Schlanger et al. 1981; Larson 1991). Cretaceous fossil evidence, including champosaurs (crocodilian-like reptiles), turtles, and breadfruit trees in Arctic regions that today are home to polar bears and permafrost, provide compelling evidence of past warmth (Tarduno et al. 1998; Jenkyns et al. 2004). Warm continental conditions are also indicated by leaf margin analyses of angiosperm floras from northeast Asia and Alaska (paleolatitudes between $68^{\circ}$ and $80^{\circ} \mathrm{N}$ ), which support mean-annual temperatures (MATs) between $\sim 8^{\circ}$ and $14^{\circ} \mathrm{C}$ (Spicer and Herman 2010). In addition, paleotemperatures inferred from the composition of membrane lipids from Cretaceous marine plankton $\left(\mathrm{TEX}_{86}\right)$ suggest that polar waters exceeded $15^{\circ} \mathrm{C}$ during summer (Jenkyns et al. 2004; Davies et al. 2009).

Paleoclimate model simulations of the Cretaceous (and other warm periods) consistently underestimate Arctic and high-latitude continental warmth and overestimate the equator-to-pole temperature gradient (Barron 1983; Poulsen et al. 1999; Poulsen 2004; Kump and Pollard 2008; Spicer et al. 2008; Zhou et al. 2008). While uncertainties in boundary conditions (e.g., geography, $\mathrm{CO}_{2}$, and land surface characteristics) and geologic proxy data may contribute, the model-data misfit is a strong indication of deficiencies in the ability of models to adequately simulate polar climates during warm periods (Poulsen 2004; Spicer et al. 2008). To further investigate this issue, we have developed mid-Cretaceous (AlbianTuronian) climate simulations using the National Center for Atmospheric Research (NCAR) CCSM, version 3 (CCSM3) with $\mathrm{CO}_{2}$ levels nearing the upper range of proxy estimates (from 1 to 16 times preindustrial atmospheric levels). To date, most Cretaceous paleoclimate modeling studies have focused on the representation of the mean climate (e.g., Barron and Peterson 1990; Brady et al. 1998; Poulsen et al. 2001; Otto-Bliesner et al. 2002; Donnadieu et al. 2006; Zhou et al. 2012). Here we evaluate both the mean climate and the unforced Arctic climate variability in our Cretaceous simulations and demonstrate that the variability is directly a function of the mean climate state. Although the Cretaceous is far from a perfect analog for a future because of differences in continental position and configuration, these simulations provide general lessons about Arctic climate variability in warmer climate states.

\section{Methodology}

The Cretaceous simulations were developed using the NCAR CCSM3, a fully coupled ocean-atmosphere-sea ice-land surface with dynamic global vegetation global climate model (Collins et al. 2006). The atmospheric model, the NCAR Community Atmosphere Model, version 3 (CAM3), is run with a T31 spectral resolution $\left[\sim\left(3.75^{\circ} \times 3.75^{\circ}\right)\right]$ and 26 vertical levels. The land surface model, the Community Land Model, version 3.0 (CLM3.0) (Dickinson et al. 2006), has the same horizontal resolution as CAM3 and is coupled to the LundPotsdam-Jena dynamic vegetation model (DVGM) (Levis et al. 2004). A river transport model routes all runoff to the oceans. River drainage routes were based on surface topography such that flow runs downhill and prevents interior drainage. The ocean model, the Parallel Ocean Model (POP) (Smith and Gent 2002), has a nominal horizontal resolution of $3.0^{\circ}$ and 25 vertical levels. Convergence of ocean gridcell volumes at the poles can require very small computational time steps to maintain stability. To avoid this problem, the grid at the North Pole is often displaced over land. In preindustrial simulations, for example, the pole is placed over Greenland (Otto-Bliesner et al. 2006b). In our Cretaceous simulations, the pole is located over Eurasia $\left(75^{\circ} \mathrm{N}, 120^{\circ} \mathrm{E}\right)$. All experiments use the same vertical and horizontal mixing parameterizations and values. Vertical mixing is represented using the fully implicit $K$-profile parameterization (KPP) mixing parameterization with a background vertical diffusivity of $0.524 \mathrm{~cm}^{2} \mathrm{~s}^{-1}$. Horizontal mixing of tracers is performed using the Gent-McWilliam parameterization, which forces mixing to occur along isopycnals. Horizontal mixing of momentum uses a parameterization that allows for anisotropic mixing. The sea ice component of CCSM uses the Community Sea Ice Model (CSIM) at the same resolution as POP with five variablethickness layers and includes an elastic-viscous-plastic (EVP) scheme. Sea ice forms through either surface cooling (i.e., formation of frazil ice), congelation at the ice base, or through flooding of snow-covered ice. Snow 
and ice albedo is a function of the spectral band (visible and near infrared), snow thickness, ice thickness, and surface temperature, which is used to approximate melting snow and ponding albedos. Brine is rejected during frazil ice formation (Briegleb et al. 2004). This low-resolution version of CCSM has been shown to produce a climatology that is comparable to higher-resolution versions (Yeager et al. 2006) and has been widely used to study past cold and warm climate (e.g., Kiehl and Shields 2005; Otto-Bliesner et al. 2006a; Winguth et al. 2010) as well as future global warming (Bryan et al. 2006).

We completed four simulations with mid-Cretaceous paleogeography (from the PALEOMAP project; Scotese 2001) and paleobathymetry (modified after Poulsen et al. 2003), reduced solar constant (99\% of present, $1353 \mathrm{~W} \mathrm{~m}^{-2}$ ) (Gough 1981), and preindustrial trace gas concentrations $\left(760 \mathrm{ppb} \mathrm{CH}_{4}\right.$ and $270 \mathrm{ppb}$ $\mathrm{NO}_{2}$ ). Because our simulations are intended to represent climate conditions that prevailed over geologic time scales, Earth's orbital characteristics (eccentricity $=0$; obliquity $=23.0^{\circ}$ ) were chosen to minimize their influence. Three simulations were run with the DGVM (Levis et al. 2004) and differ only in their atmospheric $\mathrm{CO}_{2}$ levels, which are prescribed at preindustrial (designated $1 \mathrm{xv}$ and equal to $280 \mathrm{ppmv}$ ), 10 times preindustrial (10xv; $2800 \mathrm{ppmv})$, and 16 times preindustrial levels (16xv; $4480 \mathrm{ppmv})$. A fourth simulation (10xn) was completed with 10 times preindustrial $\mathrm{CO}_{2}\left(\mathrm{pCO}_{2}\right)$ levels and bare (i.e., no vegetation) land surfaces. The mean climate simulated in these experiments, and the influence of vegetation on the climate, are described in Zhou et al. (2012). We include the bare-ground simulation in the analysis below because it demonstrates the great sensitivity of Arctic variability and ocean stability to the background climate state.

In our experience using coupled ocean-atmosphere models, the deep ocean reaches equilibrium faster when the ocean is cooling, mainly due to more vigorous convective mixing. Thus, to expedite the convergence to radiative equilibrium, all simulations are branch runs initialized from a preexisting Cretaceous experiment (Otto-Bliesner et al. 2002). The simulations were run for $2125,1637,1626$, and $1615 \mathrm{yr}$ for the $1 \mathrm{xv}, 10 \mathrm{xv}, 10 \mathrm{xn}$, and $16 x v$ experiments, respectively. Trends in global ocean temperature are small in all experiments (approximately $0.1^{\circ} \mathrm{C}$ century $^{-1}$ over the last $200 \mathrm{yr}$ ). The last $1000 \mathrm{yr}$ of each run are analyzed.

In the analysis that follows, climate anomalies were calculated by removing a second-order polynomial least squares fit for the $1 \mathrm{xv}, 10 \mathrm{xn}$, and $16 \mathrm{xv}$ experiments and by removing the mean value for the $10 x v$ experiment prior to analysis. We treat the $10 x v$ experiment differently because there are clearly two stable modes of
Arctic climate (one between the years 500 and 800 and the other after year 900); a removal of least squares fit would introduce artificial variability to the time series. To filter high-frequency (interannual) variability, an 11-yr running mean was applied to all data. Statistical significance is computed using a two-sided $t$ test. In our analyses, the Arctic is defined as the region north of $70^{\circ} \mathrm{N}$.

\section{Simulation of Cretaceous climate}

\section{a. Cretaceous mean climate}

At preindustrial greenhouse gas (GHG) levels (1xv), the Cretaceous mean-annual global surface temperature is $13.6^{\circ} \mathrm{C}$ (Table 1 ), approximately $0.1^{\circ} \mathrm{C}$ greater than a preindustrial CCSM3 simulation (Otto-Bliesner et al. 2006b), despite a reduced solar luminosity. The higher Cretaceous temperature is mainly attributed to the larger ocean fraction in the Cretaceous relative to the modern, which reduces low-latitude albedo and enhances surface evaporation leading to greater atmospheric humidity and greenhouse forcing. Cretaceous Antarctic surface temperatures are substantially higher than preindustrial because of the absence of an Antarctic ice sheet; nonetheless, the continental interior remains snow-covered throughout the year with annual surface temperatures below $-20^{\circ} \mathrm{C}$ (Fig. 1a). The Northern Hemisphere sea ice area $\left(15.6 \times 10^{6} \mathrm{~km}^{2}\right)$ is $17.2 \%$ higher than in a preindustrial CCSM3 simulation, a consequence of larger ocean area (by 16.1\%) in the Cretaceous Arctic. Perennial sea ice covers the Arctic Ocean, the southward limb of the subpolar gyre in the Northern Pacific, and the Antarctic margin (Fig. 5a).

In the high $\mathrm{CO}_{2}$ simulations, mean-annual global surface temperatures are $23.1^{\circ} \mathrm{C}(10 \mathrm{xn}), 24.0^{\circ} \mathrm{C}(10 \mathrm{xv})$, and $25.6^{\circ} \mathrm{C}(16 \mathrm{xv})$ (Table 1). Mean-annual low-latitude sea surface temperatures (SSTs) are similar between experiments and range between $30^{\circ}$ and $34^{\circ} \mathrm{C}$ (Table 1 ; Fig. 1 ), values that are consistent with proxy paleotemperatures estimated using oxygen isotope and $\mathrm{TEX}_{86}$

TABLE 1. Mean-annual surface (MAT) and ocean temperatures averaged over the final $50 \mathrm{yr}$ of each Cretaceous simulation $(1 \mathrm{xv}$ has 280 ppmv $\mathrm{CO}_{2}$ and dynamic vegetation; 10xn has 2800 ppmv $\mathrm{CO}_{2}$ and bare ground; $10 \mathrm{xv}$ has 2800 ppmv $\mathrm{CO}_{2}$ and dynamic

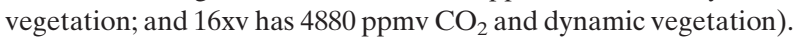
In the $10 \mathrm{xv}$ case, values are shown for the postwarming period (see text for description).

\begin{tabular}{lrrrr}
\hline \hline & $1 \mathrm{xv}$ & $10 \mathrm{xn}$ & $10 \mathrm{xv}$ & $16 \mathrm{xv}$ \\
\hline Global MAT $\left({ }^{\circ} \mathrm{C}\right)$ & 13.6 & 23.1 & 24.0 & 25.6 \\
Low-latitude $\left(30^{\circ} \mathrm{S}-30^{\circ} \mathrm{N}\right)$ & 23.6 & 30.7 & 31.0 & 32.7 \\
$\quad$ MAT $\left({ }^{\circ} \mathrm{C}\right)$ & & & & \\
Arctic $\left(70^{\circ}-90^{\circ} \mathrm{N}\right) \mathrm{SST}\left({ }^{\circ} \mathrm{C}\right)$ & -1.4 & 6.3 & 8.4 & 9.5 \\
Global ocean temperature $\left({ }^{\circ} \mathrm{C}\right)$ & 1.9 & 7.1 & 7.8 & 9.0 \\
\hline
\end{tabular}


a) $1 \times v$

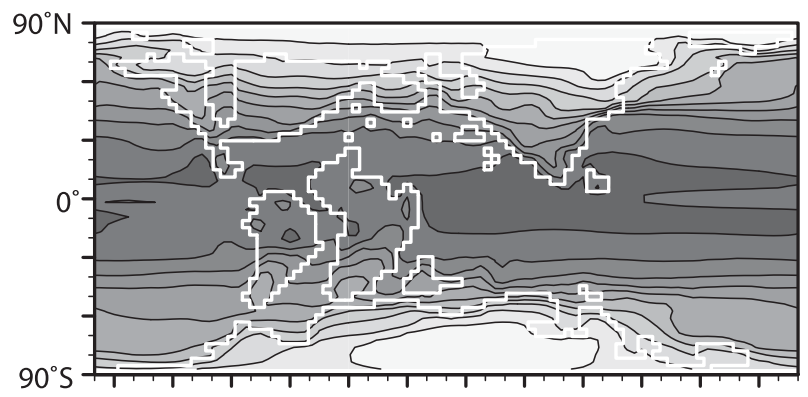

c) $10 x v$

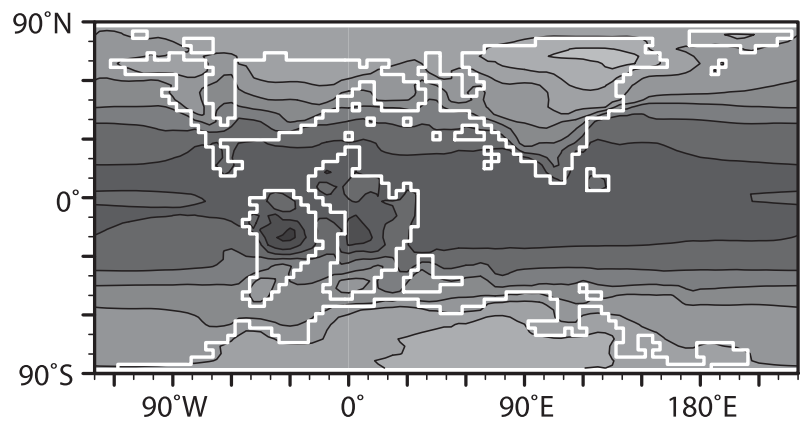

b) $10 \times n$

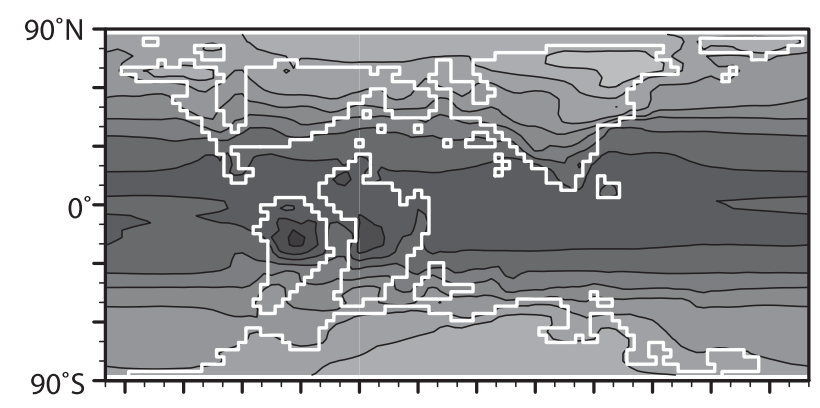

d) $16 \mathrm{xv}$

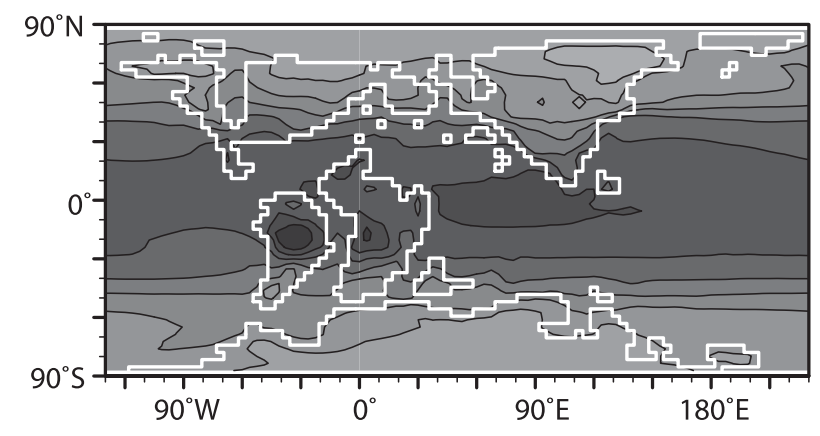

Surface temperature $\left({ }^{\circ} \mathrm{C}\right)$

\begin{tabular}{|l|l|l|l|l|l|l|l|l|l|l|}
\hline & & & & & & & & & & \\
\hline-20 & -10 & 0 & 10 & 20 & 30 & 40
\end{tabular}

FIG. 1. Mean-annual surface temperature $\left({ }^{\circ} \mathrm{C}\right.$ ) for the (a) $1 \mathrm{xv}$, (b) 10xn, (c) 10xv, and (d) 16xv experiments. MATs are averaged over the final $100 \mathrm{yr}$ of each CCSM3 experiment. Continental outlines are shown as thick white lines.

paleothermometry (e.g., Norris et al. 2002; Wilson et al. 2002; Schouten et al. 2003). Arctic SSTs are 6.3 (10xn), $8.4^{\circ}(10 \mathrm{xv})$, and $9.5^{\circ} \mathrm{C}(16 \mathrm{xv})$ in the annual mean and $10.0^{\circ}(10 \mathrm{xn}), 12.8^{\circ}(10 \mathrm{xv})$, and $14.0^{\circ} \mathrm{C}(16 \mathrm{xv})$ in JuneJuly-August. Cretaceous SST estimates using the TEX 86 method indicate that summer Arctic temperatures likely exceeded $15^{\circ} \mathrm{C}$ (Jenkyns et al. 2004; Davies et al. 2009), indicating that even with extreme $\mathrm{pCO}_{2}$ levels CCSM3 underestimates high-latitude SSTs, a problem that is not unique to CCSM3 (e.g., Poulsen 2004; Spicer et al. 2008). Winter sea ice develops along the coast of Eurasia in the North Pacific and Arctic Oceans in the 10x experiments, but is absent in the 16x experiment.

The $1 \mathrm{xv}$ Cretaceous experiment has a global average ocean temperature of $1.9^{\circ} \mathrm{C}$ and exhibits a vigorous overturning circulation in the paleo-Pacific Ocean. Deep waters are formed in both the northern North Pacific Ocean and the South Pacific Ocean along the Antarctic coast. The maximum intensity of the Northern Hemisphere meridional overturning circulation (NMOC) at depths greater than $500 \mathrm{~m}$ is $20.6 \mathrm{~Sv}\left(1 \mathrm{~Sv} \equiv 10^{6} \mathrm{~m}^{3} \mathrm{~s}^{-1}\right.$; Fig. 2a), somewhat greater than the preindustrial North Atlantic
MOC intensity (21.0 Sv; Otto-Bliesner et al. 2006b). Global average ocean temperatures rise to $7.1^{\circ}(10 \mathrm{xn})$, $7.8^{\circ}(10 \mathrm{xv})$, and $9.0^{\circ} \mathrm{C}(16 \mathrm{xv})$ in the high $\mathrm{CO}_{2}$ simulations (Table 1). In general, the Cretaceous NMOC weakens and shallows with higher $\mathrm{pCO}_{2}$ and warmer temperatures (Figs. 2a-d; Table 1), a response that is consistent with future warming scenarios with the same model resolution (Bryan et al. 2006). However, the NMOC response to $\mathrm{pCO}_{2}$ is highly nonlinear and as described below is linked to heat and salinity transports in the North Pacific Ocean. The change in NMOC intensity between the $1 \mathrm{xv}$ and $10 \mathrm{xn}$ experiments, despite a significant global temperature increase, is small $(\sim 1 \mathrm{~Sv})$. In contrast, NMOC intensity differs by $8.7 \mathrm{~Sv}$ between the $10 \mathrm{xv}$ and $16 \mathrm{xv}$ experiments. At higher $\mathrm{pCO}_{2}$, deep waters form mainly in the northern North Pacific Ocean.

\section{b. Low-frequency Arctic SST variability}

The Cretaceous 1xv simulation exhibits low-frequency variability that is similar in amplitude and frequency to modern Arctic variability (e.g., Goosse and Holland 2005; Polyakov and Johnson 2000). Arctic mean-annual 
a) $1 x v$

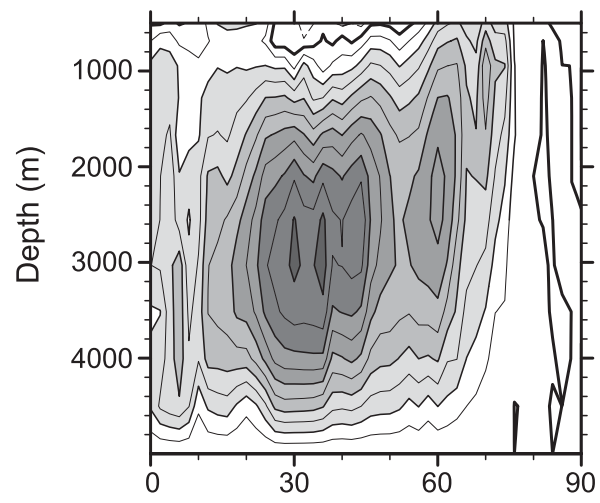

d) $16 x v$

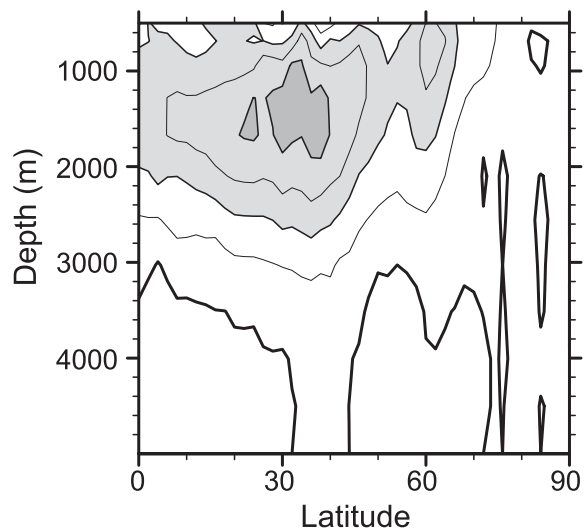

b) $10 x n$

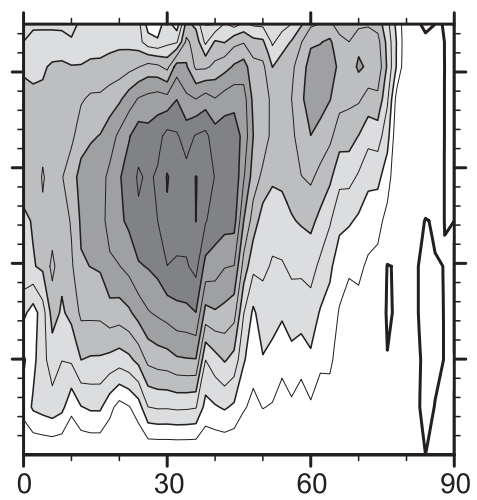

e) 10xv, yrs 701-800

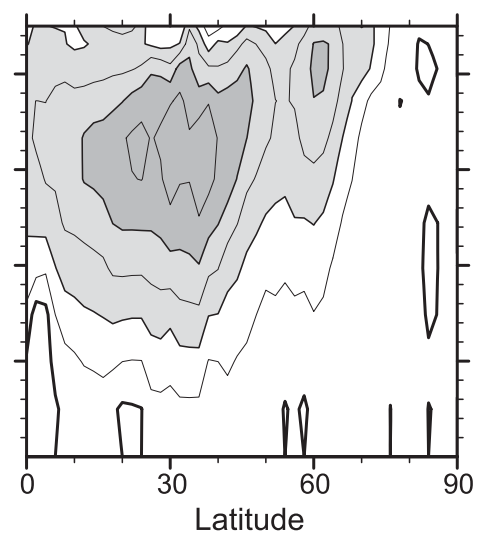

c) $10 x v$

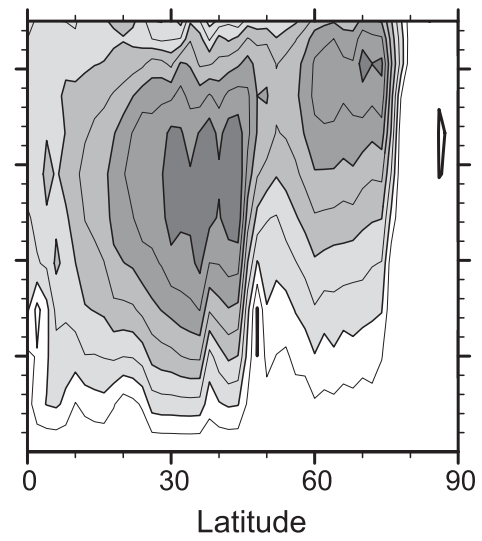

FIG. 2. NMOC streamfunction (Sv) for the (a) 1xv, (b) 10xn, (c) 10xv, and (d) 16xv experiments. Streamfunctions are averaged over the last $100 \mathrm{yr}$ of each simulation. (e) NMOC is shown for years 701-800 of the $10 \mathrm{xv}$ experiment, which represents the prewarming phase (see text for explanation). Positive (negative) streamfunction values represent clockwise (counter) flow.

SSTs vary at multidecadal frequencies with dominant periods of $\sim 62$ and $99 \mathrm{yr}$ and standard deviation of $0.5^{\circ} \mathrm{C}$ (Figs. 3a and 4a). The peak-to-peak amplitude of Arctic SSTs is up to $2^{\circ} \mathrm{C}$. Locally SST anomalies exceed $5^{\circ} \mathrm{C}$ in the North Pacific and are associated with expansion/retreat of the sea ice margin (Fig. 5). Anomalies larger than one standard deviation last no longer than $50 \mathrm{yr}$ during the 1000 -yr iteration. Arctic SST variability is tightly linked to sea ice. The maximum time-lag correlation between Arctic SST and sea ice is $\sim 0.98$ (99\%) with 0 lag.

Arctic SST variability on multidecadal time scales is damped and lengthened with higher $\mathrm{pCO}_{2}$ and the corresponding reduction in sea ice. The 10x experiments demonstrate multidecadal SST variability with peak-topeak amplitudes of $<1.0^{\circ} \mathrm{C}$ (Figs. $3 \mathrm{~b}, \mathrm{c}$ ), less than that exhibited in the $1 \mathrm{xv}$ case. In the $16 \mathrm{xv}$ experiment, the multidecadal variability is further diminished with peakto-peak multidecadal changes of $<0.6^{\circ} \mathrm{C}$ and no significant period. In the $10 \mathrm{x}$ cases, multidecadal variability is surpassed in magnitude by centennial-scale and abrupt climate changes. In the 10xn experiment, centennial SST variations (with a dominant period of $\sim 333 \mathrm{yr}$, Fig. $4 \mathrm{~b}$ ) have peak-to-peak amplitudes of $>2^{\circ} \mathrm{C}$, comparable to the maximum multidecadal amplitudes observed in the $1 \mathrm{xv}$ experiment, that persist up to $150 \mathrm{yr}$ (Fig. 3b). The $10 \mathrm{xv}$ experiment lacks persistent centennial variability, but undergoes an abrupt Arctic climate warming of $\sim 2^{\circ} \mathrm{C}$ starting at year 805 . The warming occurs over a 30 -yr period at a rate of $0.53^{\circ} \mathrm{C} \mathrm{decade}{ }^{-1}$ and endures for the remainder of the run $(>800 \mathrm{yr})$. (The periods before and after the abrupt warming are referred throughout the text as prewarming and postwarming phases.) Arctic warming events in both $10 \mathrm{x}$ simulations are characterized by SST increases of up to $5^{\circ} \mathrm{C}$ in the Arctic Ocean near the Bering Strait and in the midlatitude western Pacific Ocean (Figs. 6a,c,d).

\section{c. Sources of Cretaceous Arctic SST variability}

In the modern Arctic, low-frequency SST variability is dominated by ocean exchange and heat transport 

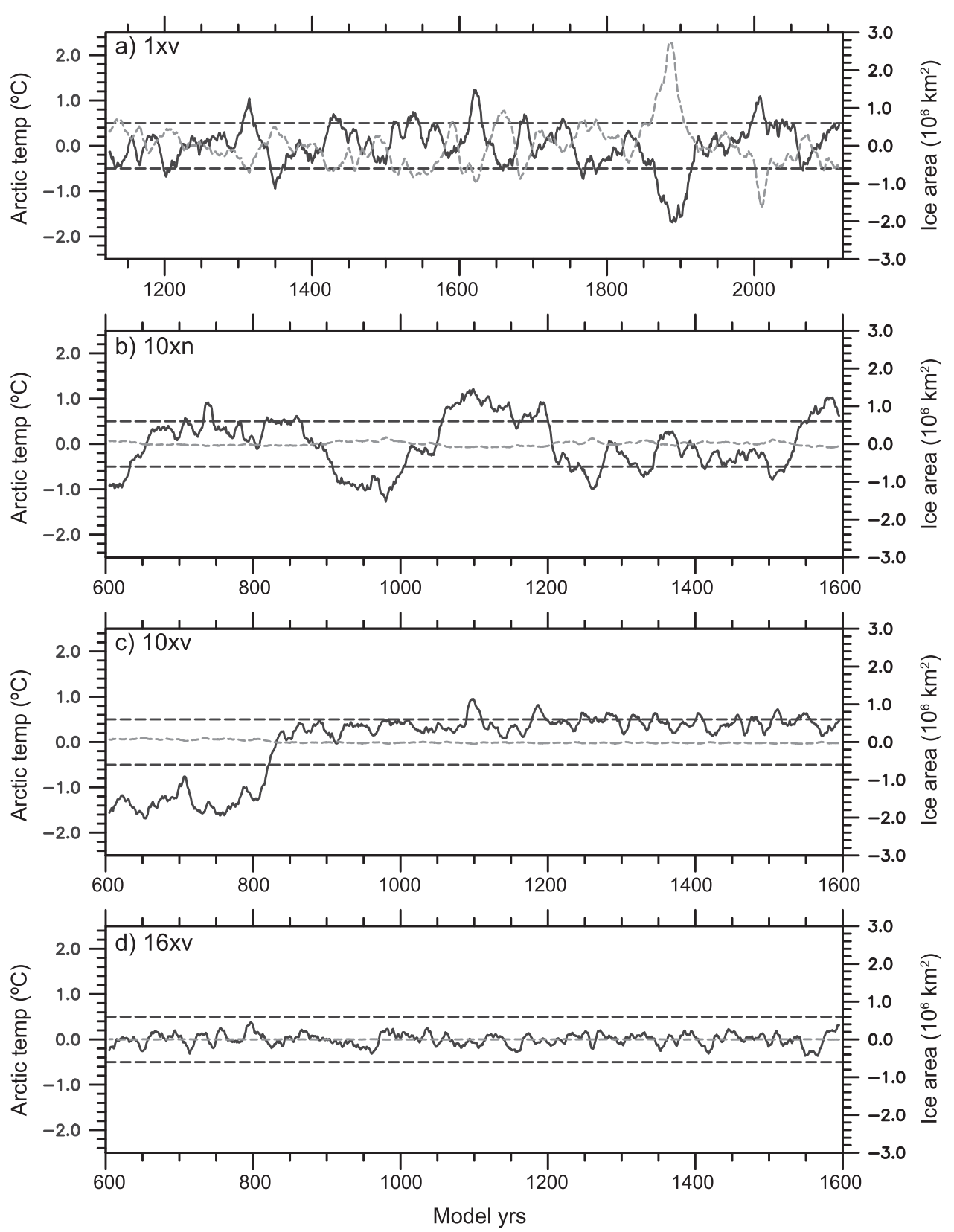

FIG. 3. Time series of Arctic temperature anomalies $\left({ }^{\circ} \mathrm{C}\right.$; black line) and Arctic sea-ice area anomalies $\left(10^{6} \mathrm{~km}^{2}\right.$; gray dashed line) for the (a) $1 \mathrm{xv}$, (b) 10xn, (c) 10xv, and (d) 16xv experiments. Black dashed lines show the one standard deviation of Arctic temperature in the $1 \mathrm{xv}$ experiment. Time series are filtered using an 11-yr running mean.

(OHT) into the Barents Sea (Goosse and Holland 2005; Jungclaus and Koenigk 2010). Because the North Atlantic basin did not undergo extensive rifting until the mid-Paleocene or Early Eocene and is therefore very narrow in our experiments, North Atlantic Ocean exchange with the Arctic is very limited in the Cretaceous simulations. Rather, the greatest ocean exchange with the Arctic occurs in the northern North Pacific through a shallow ( $<200 \mathrm{~m}$ in our simulations) Bering Strait, which was also an important avenue of faunal interchange until the Late Cretaceous (Iba et al. 2011). In this region, as in the modern climate, Arctic low-frequency temperature variability is significantly correlated with ocean heat exchange in the Cretaceous $1 \mathrm{xv}$ and $10 \mathrm{xn}$ experiments and in the prewarming phase of the $10 \mathrm{xv}$ simulation (Figs. 7a-c; Table 2). The positive correlation 
a) $1 \times v$

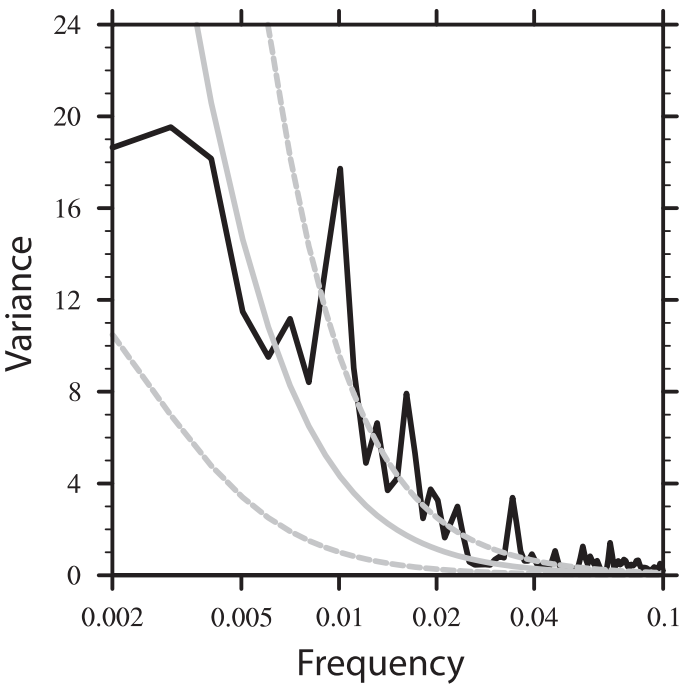

b) $10 \times n$

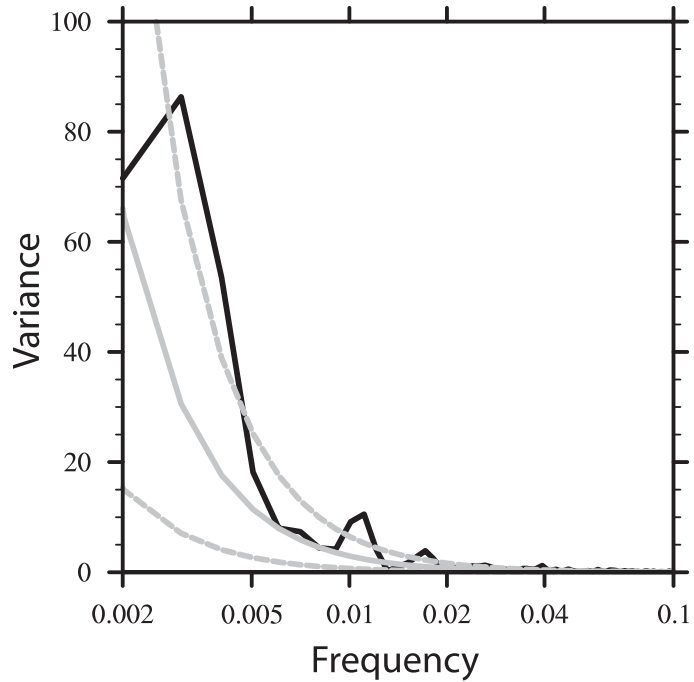

FIG. 4. Periodogram of Arctic surface temperatures for (a) 1xv and (b) 10xn simulations. The spectrum is calculated using a forward Fourier transform and hanning window over the detrended 1000-yr Arctic surface temperatures. Gray lines signify the red noise spectrum (solid line) and the 5\% and 95\% confidence intervals (dashed lines). Spectral values (black line) that are greater than the red noise upper confidence level are interpreted as statistically significant.

is strongest when $\mathrm{OHT}$ anomalies at $70^{\circ} \mathrm{N}$ lead Arctic SST anomalies by a few years with maximum correlations of 0.5 in the $1 \mathrm{xv}$ run $(\sim 2$-yr lead $)$ and $>0.9$ in the $10 \mathrm{xn}$ and prewarming phase of the $10 \mathrm{xv}$ runs $(10 \mathrm{xv}$ pre; $\sim 5$-yr lead). In contrast, OHT anomalies lag Arctic SST anomalies in the postwarming phase (years 900-1600) of the $10 \mathrm{xv}$ experiment $(10 \mathrm{xv}$ post $)$ and are not significantly correlated in the 16xv experiment (Figs. 7d,e; Table 2).

OHT variability in the modern Arctic has been linked to large-scale atmospheric circulation changes (e.g., Dickson et al. 2000), large-scale oceanic changes involving the North Atlantic meridional overturning circulation (e.g., Delworth et al. 1993), or through regional coupled ocean-atmosphere processes (e.g., Bengtsson et al. 2004). To evaluate the role of high-latitude atmospheric processes, we examine and compare atmospheric heat transport (AHT) at $70^{\circ} \mathrm{N}$ to OHT (Fig. 7). AHT anomalies are similar in magnitude and are significantly anticorrelated $(r=-0.69,-0.94$, and -0.81$)$ with OHT in the $1 \mathrm{xv}, 10 \mathrm{xn}$, and prewarming phase of the $10 \mathrm{xv}$ experiments (Fig. 7; Table 2). The strong linkage between AHT and OHT weakens in the postwarming phase of the $10 \mathrm{xv}$ and $16 \mathrm{xv}$ experiments $(r=-0.38$ and -0.31$)$. AHT is also significantly $(r=-0.45)$ anticorrelated a) Sea-ice fraction

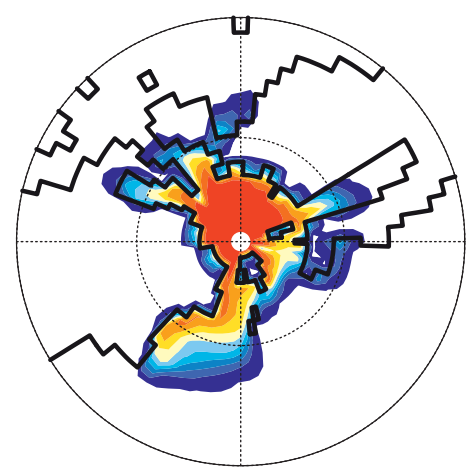

b) Sea-ice anomaly

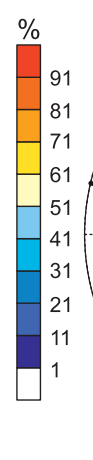

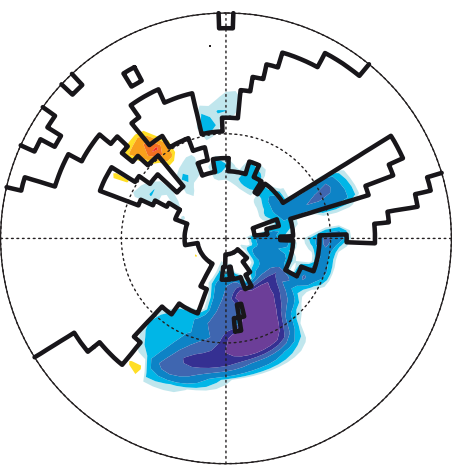

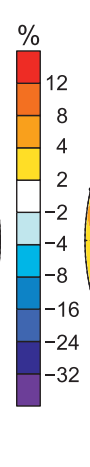

c) Surface temperature anomaly

FIG. 5. Mean-annual (a) sea-ice fraction (\%), (b) sea-ice fraction anomaly (\%), and (c) surface temperature anomaly $\left({ }^{\circ} \mathrm{C}\right)$ for the $1 \mathrm{xv}$ simulation. Anomalies represent the difference between warm (average of years 1615-25) and cold (average of years 1655-65) events. 
a) $10 x n, y r 1100-970$

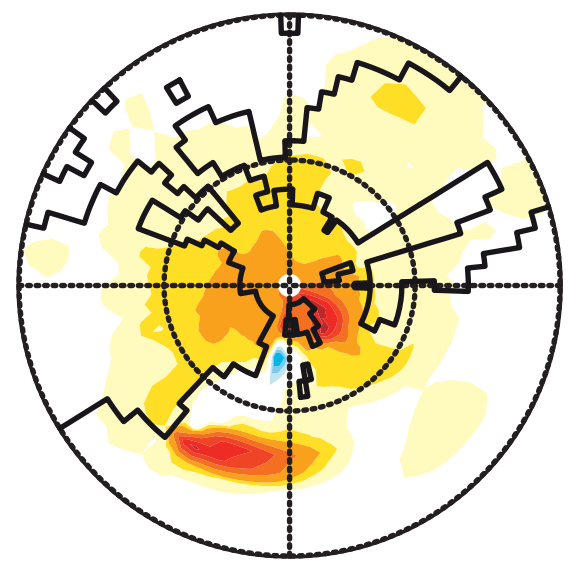

C) $10 x v$, yr $900-700$

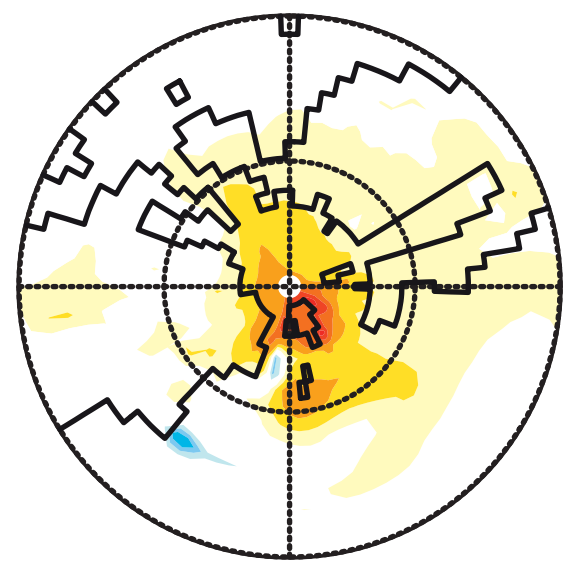

b) $10 x n, y r 1300-1100$

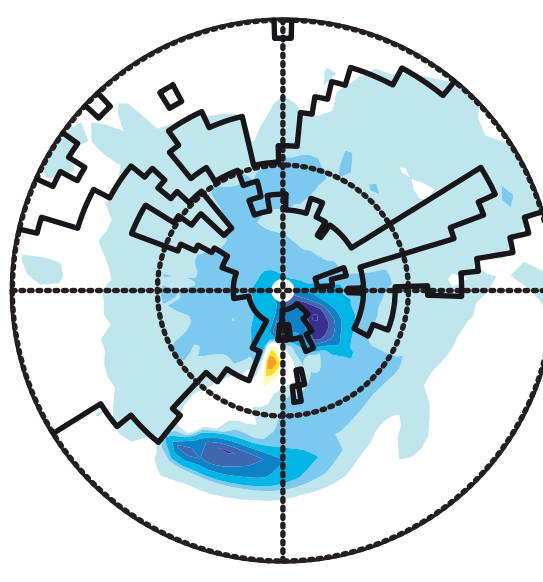

d) $10 x v$, yr 1600-900

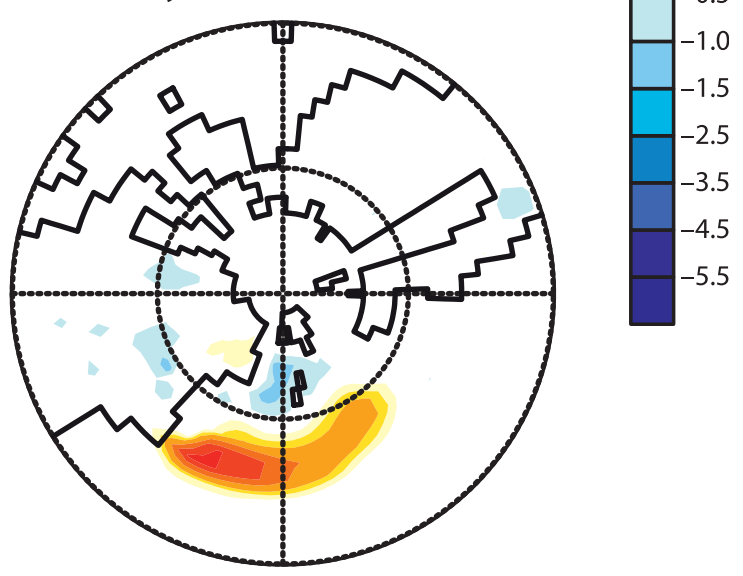

FIG. 6. Mean-annual surface temperature differences $\left({ }^{\circ} \mathrm{C}\right)$ between warm and cold events for the (a),(b) 10xn and (c),(d) 10xv simulations. Compare with Figs. 3b,c. The temperature anomaly pattern is similar between events in the 10xn case with temperature changes centered over the northern North Pacific-Arctic and the midlatitude western North Pacific. In the 10xv simulation, (c) Arctic warming precedes (d) midlatitude warming by hundreds of years.

with Arctic surface temperature in the $1 \mathrm{xv}$ case with a lead of $\sim 13 \mathrm{yr}$, whereas in the 10x experiments maximum anticorrelations $(<-0.8)$ are essentially instantaneous (Figs. 7a-c; Table 2). This analysis suggests that atmospheric processes may drive ocean heat transport in the $1 \mathrm{xv}$ case, but are likely responding to upper-ocean conditions in the 10x simulations.

To evaluate the relationship between MOC and OHT in our experiments, we compare NMOC, which serves a similar role in the Cretaceous experiments as the modern North Atlantic MOC, and mid- and high-latitude oceanic heat transport. In the $1 \mathrm{xv}, 10 \mathrm{xn}$, and $10 \mathrm{xv}$ experiments, NMOC exhibits variability on multidecadal and longer time scales with maximum amplitudes of $\sim 6 \mathrm{~Sv}$ (Fig. 8), representing low-frequency changes of $>20 \%$ (Fig. 8). NMOC is tightly linked to midlatitude $\left(44^{\circ} \mathrm{N}\right)$ OHT in all Cretaceous experiments (Fig. 8) with regression coefficients of $0.027\left(1 \mathrm{xv}, r^{2}>0.9\right), 0.034$ $\left(10 \mathrm{xn}, r^{2}>0.9\right), 0.035\left(10 \mathrm{xv}, r^{2}>0.9\right)$, and $0.032 \mathrm{PW} \mathrm{Sv}^{-1}$ $\left(16 \mathrm{xv}, r^{2}=0.77\right)$ at a 0 -yr lag. However, in the $1 \mathrm{xv}$, $10 \mathrm{xn}$, and prewarming phase of the $10 \mathrm{xv}$ experiment, maximum significant correlations occur when highlatitude $\left(70^{\circ} \mathrm{N}\right) \mathrm{OHT}$ is leading NMOC (Table 2), suggesting that the overturning circulation is not driving OHT and SST anomalies in the Arctic. In the 16xv run, NMOC leads high-latitude OHT, but accounts for less than $16 \%$ of the OHT variability $(r=0.36$ at a phase of 2-3 yr, Table 2).

The character and source of Arctic climate variability differs as a function of mean state. In the following sections, we examine mechanisms of Arctic variability under different $\mathrm{CO}_{2}$ levels. 
a) $1 x v$

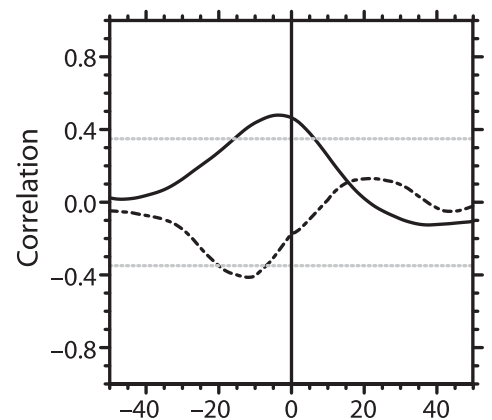

d) $10 x v$ yrs $901-1600$

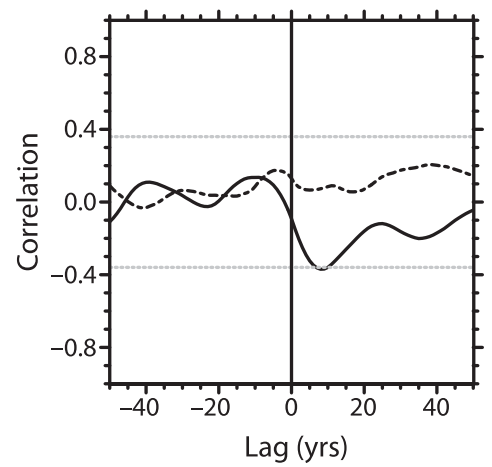

b) $10 \mathrm{xn}$

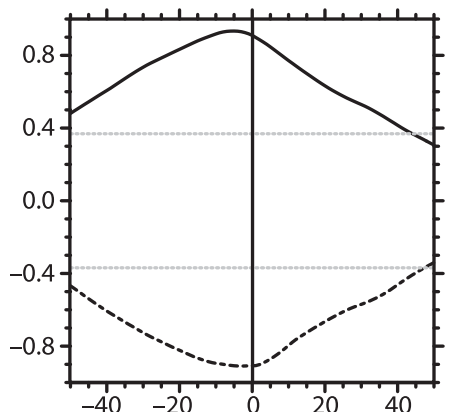

e) $16 x v$

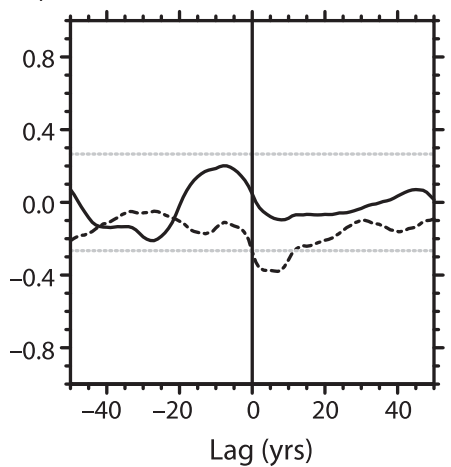

c) $10 x v$ yrs $600-900$

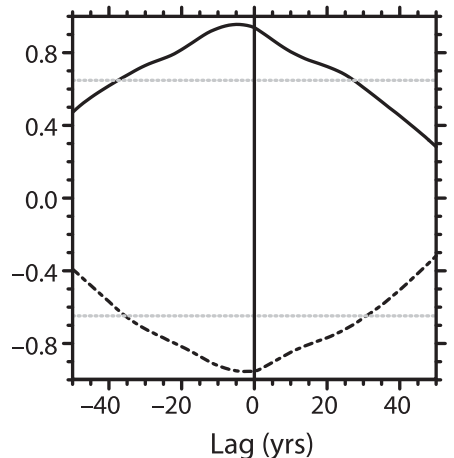

FIG. 7. Lag correlation between northward heat transport (in PW $=10^{15} \mathrm{~W}$ ) and Arctic surface temperature $\left({ }^{\circ} \mathrm{C}\right.$ ). Correlations are shown for experiments (a) 1xv between 1120 and 2120; (b) 10xn between 600 and 1600; (c) 10xv between 600 and 900; (d) 10xv between 900 and 1600; and (e) 16xv between 600 and 1600. The solid line denotes ocean heat transport at $70^{\circ} \mathrm{N}(\mathrm{OHT} 70 \mathrm{~N})$. The dashed line is atmospheric heat transport at $70^{\circ} \mathrm{N}(\mathrm{AHT} 70 \mathrm{~N})$. By definition, positive (negative) lag indicates that Arctic temperature anomalies lead (lag) heat transports. The two gray dashed lines show the $99 \%$ significance level.

\section{d. Cretaceous Arctic variability under preindustrial (1 times) $\mathrm{CO}_{2}$ levels}

At preindustrial $\mathrm{CO}_{2}$ levels, and in contrast with simulations under elevated $\mathrm{CO}_{2}$, Arctic temperature variability is tightly coupled and driven by North Pacific sea ice extent (Fig. 3a). The largest warming and cooling events are associated with below- and above-average sea ice areas. Moreover, both sea surface temperature anomalies and sea ice expansion-retreat are centered in the northern North Pacific (Fig. 5). As in the modern, sea ice variability is likely linked to unforced, internal atmospheric variability. To characterize this variability, we calculate the empirical orthogonal function (EOF) of annual mean sea level pressure (SLP) anomalies. The leading EOF, which accounts for $28.5 \%$ of the variability, is characterized by opposite SLP anomalies over the Arctic and midlatitudes (Fig. 9a), a pattern that is

TABLE 2. Lag correlations. Correlations represent the maximum absolute correlation coefficient between ocean heat transport $70^{\circ} \mathrm{N}$ (OHT), atmospheric heat transport at $70^{\circ} \mathrm{N}$ (AHT), Northern Hemisphere meridional overturning circulation (NMOC), cloud radiative forcing (CRF), and Arctic surface air temperature (SAT). Lag phases have units of years. A positive (negative) lag indicates that the leftmost variable leads (lags) the rightmost variable. All correlations are significant at the $99 \%$ level. Table entries without values indicate that the correlation is not significant.

\begin{tabular}{|c|c|c|c|c|c|}
\hline & $1 \mathrm{xv}$ & $10 x n$ & $10 \mathrm{xv}$ pre & $10 \mathrm{xv}$ post & $16 \mathrm{xv}$ \\
\hline OHT/SAT & $0.50(2)$ & $0.92(5)$ & $0.97(5)$ & $-0.39(9)$ & - \\
\hline АНT/OHT & $-0.69(3)$ & $-0.94(-2$ to 0$)$ & $-0.81(-1)$ & $-0.38(-2$ to -1$)$ & $-0.31(-1)$ \\
\hline $\mathrm{AHT} / \mathrm{SAT}$ & $-0.41(11$ to 14$)$ & $-0.91(-1$ to 6$)$ & $-0.94(-4$ to 0$)$ & - & $-0.38(-7$ to -4$)$ \\
\hline OHT/NMOC & $0.71(4$ to 5$)$ & $0.79(5$ to 8$)$ & $0.62(50)$ & - & $0.37(-4$ to -2$)$ \\
\hline CRF/SAT & $-0.72(-6$ to 0$)$ & $0.87(0)$ & $0.92(0)$ & $0.69(0)$ & $0.59(0)$ \\
\hline
\end{tabular}



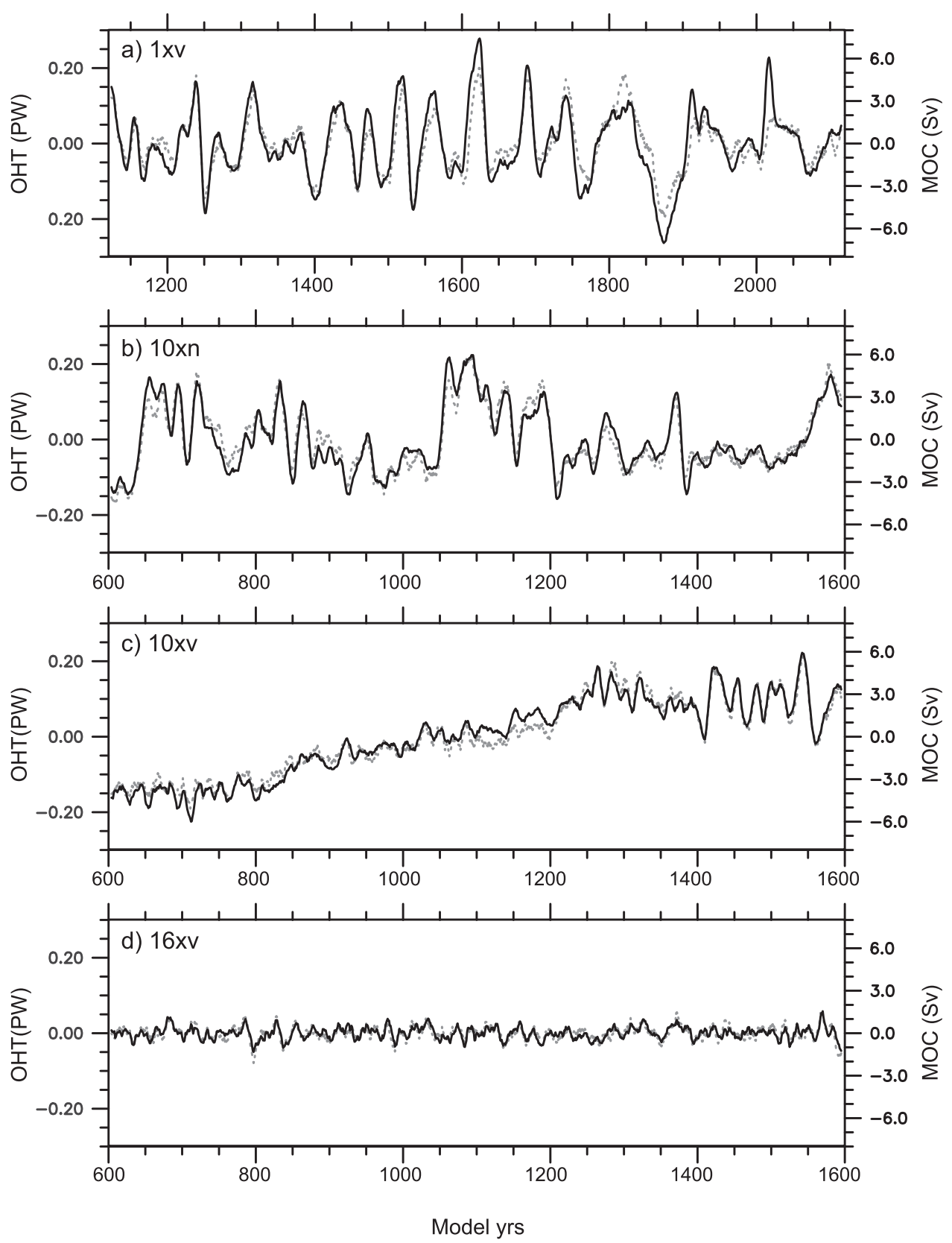

FIG. 8. Time series of northward OHT anomalies (PW) at $44^{\circ} \mathrm{N}$ (dashed gray line) and maximum NMOC anomalies (black line). OHT and NMOC anomalies are shown for the (a) 1xv, (b) 10xn, (c) 10xv, and (d) 16xv experiments. NMOC is the maximum Northern Hemisphere meridional overturning streamfunction (Sv) at depths $>500 \mathrm{~m}$.

reminiscent of the modern Arctic Oscillation, an important source of modern sea ice variability (Rigor et al. 2002). The leading EOF of SLP is anticorrelated with Northern Hemisphere sea ice area $(r=-0.43$ with a lead of $0-4 \mathrm{yr})$, suggesting a modest link between anomalously high (low) polar SLP and low (high) sea ice cover. The second and third EOFs of SLP account for $15.5 \%$ and $8.3 \%$ of the variability, respectively, and exhibit patterns with variability centered over the northern North Pacific, the region of greatest sea ice activity (cf. Figs. $5 b$ and $9 b, c)$. As such, these patterns are likely symptoms rather than causes of sea ice melting-growing.

Regardless of origin, sea ice change is amplified through positive feedbacks involving ocean heat transport in the 
a) EOF1, $28.5 \%$

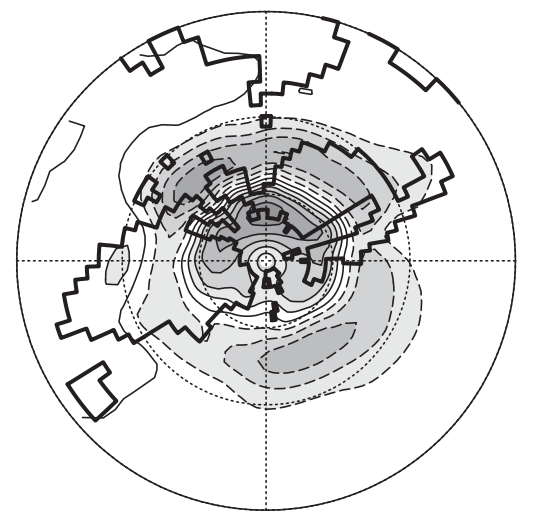

b) EOF2, $15.5 \%$

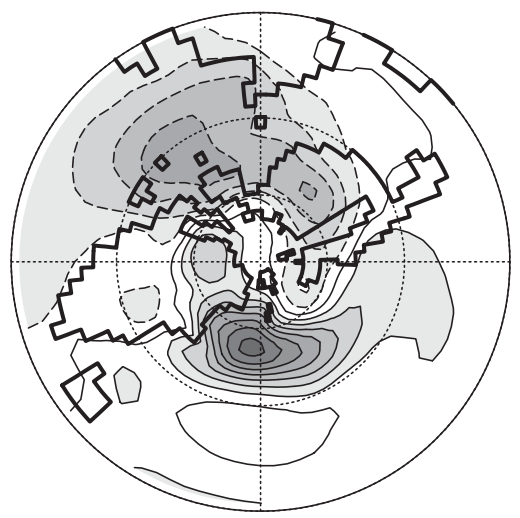

c) EOF3, $8.3 \%$

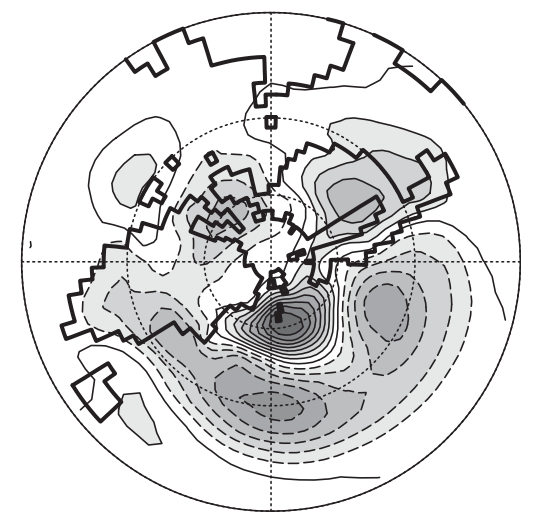

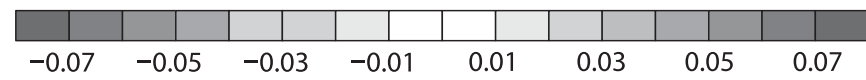

FIG. 9. Leading EOFs of Northern Hemisphere sea level pressure anomalies for the last $1000 \mathrm{yr}$ of the $1 \mathrm{xv}$ experiment. The total variance explained by each pattern is indicated. The black lines are continental outlines. The polar plot extends to $0^{\circ}$ latitude.

northern North Pacific. In support of this conclusion, sea-ice area is highly anticorrelated $(r=-0.78)$ with high-latitude OHT with a lead of $0-1 \mathrm{yr}$. The barotropic streamfunction response to warming is consistent with this result: the streamfunction decreases (indicating an increase in cyclonic flow) in the western North Pacific (Figs. 10a,d), enhancing warm water advection and heat transport into previously sea ice-covered areas. Lowlevel warming in the northwest North Pacific also disrupts the low-level inversion leading to a reduction in stratus clouds. In CCSM, stratus clouds have a positive radiative forcing over sea ice, where they serve to reduce shortwave reflection, and a negative radiative forcing over lower albedo surfaces. Over the subarctic, the former influence prevails; the reduction in low cloud fraction by up to 0.12 (expressed as \% in Figs. 11a-c) lowers net cloud radiative forcing and serves as a negative feedback on surface temperature (Figs. 11a,d and 12a; Table 2).

\section{e. Cretaceous Arctic variability under elevated (10 times) $\mathrm{CO}_{2}$ levels}

In the absence of substantial sea ice, upper-ocean processes drive simulated Arctic surface temperature variability in the $10 \mathrm{xn}$ and prewarming phase of the $10 \mathrm{xv}$ experiments. Heat and salinity transport into the Arctic occurs primarily by advection from the subpolar gyre through the Bering Strait. Flow exits the Arctic and reenters the subpolar gyre through a shallow seaway on the Siberian platform. High-latitude mass transport (as indicated by the barotropic streamfunction with negative values representing counterclockwise flow) and OHT into the Arctic through the subpolar gyre are highly correlated $(|r|=0.8$ at the $99 \%$ confidence level at 0 lag) (Fig. 13). During warming episodes, the mass transport of water from the northern North Pacific and through the Arctic increases by $\sim(2-3)$ Sv leading to OHT increases of $\sim(0.08-0.09)$ PW (Figs. 10b,c and 13). This relationship occurs on both centennial time scales in the 10xn experiment (Fig. 13a) and in association with the abrupt warming event in the 10xv experiment (Fig. 13b). Coincident with increases in Arctic exchange, the intensity of the western limb of the subpolar gyre decreases by more than $10 \mathrm{~Sv}$, indicating that the gyre center moves eastward and the total subpolar gyre mass transport decreases (Figs. 10e,f).

Low-frequency variability in OHT and mass transport are closely associated with salinity advection from the North Pacific to the Arctic Ocean. During warm events, seawater salinity increases throughout the Arctic by as much as 5 psu in the vicinity of the Bering Strait (Fig. 14). In both 10x experiments, salinity in the Pacific sector of the Arctic (averaged over $75^{\circ}-85^{\circ} \mathrm{N}, 160^{\circ}-240^{\circ} \mathrm{E}$ ) is highly correlated with mass transport through the Bering Strait (10xn, $r=0.93$ with a lag of -3 to $0 \mathrm{yr}$; $10 \mathrm{xv}$, $r=0.97$ with a lag of -2 to $0 \mathrm{yr}$ ), signifying a mechanistic link between salinity and transport. Salinity advection sustains mass transport by lowering the halosteric height of the water column in the Arctic and enhancing the sea surface topographic gradient between subpolar and polar regions by up to $60 \mathrm{~cm}$ (not shown). The 
a) $1 x v$

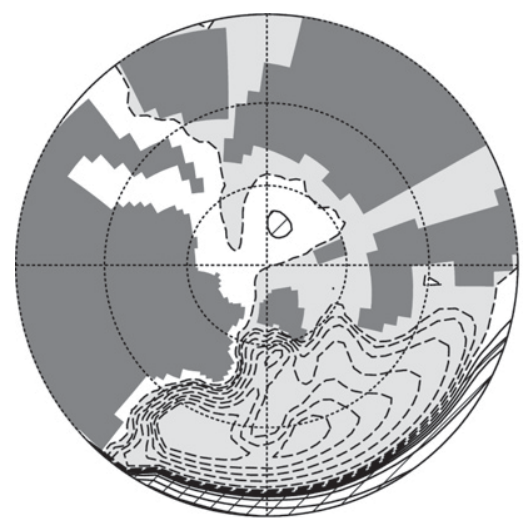

d) $1 \times x$, warm - cold

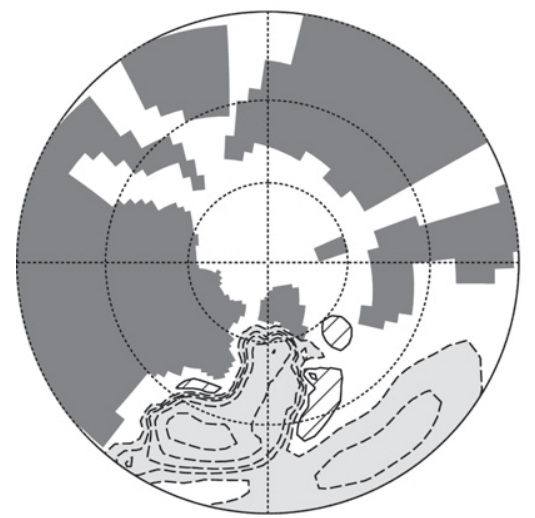

b) $10 \mathrm{xn}$

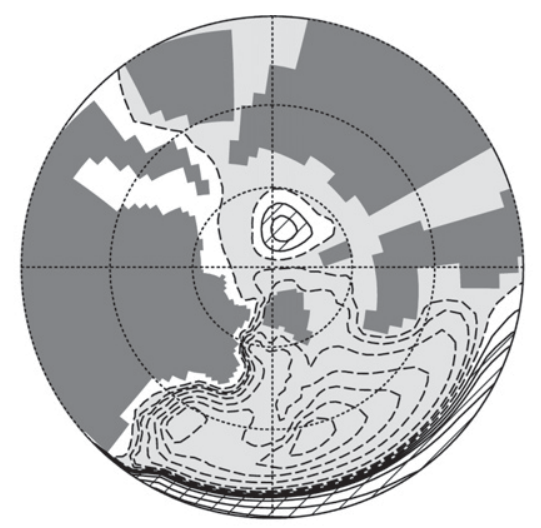

e) 10xn, warm - cold

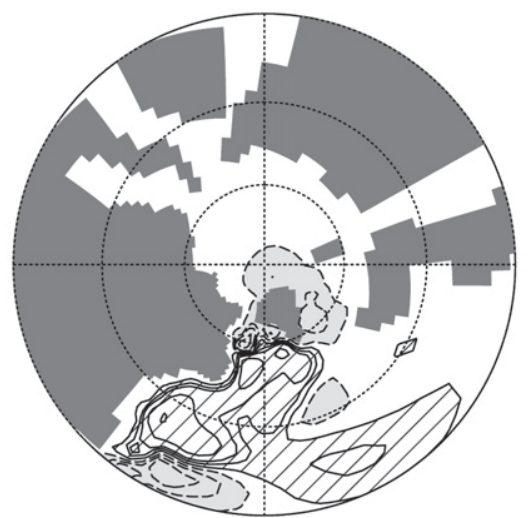

c) $10 x v$

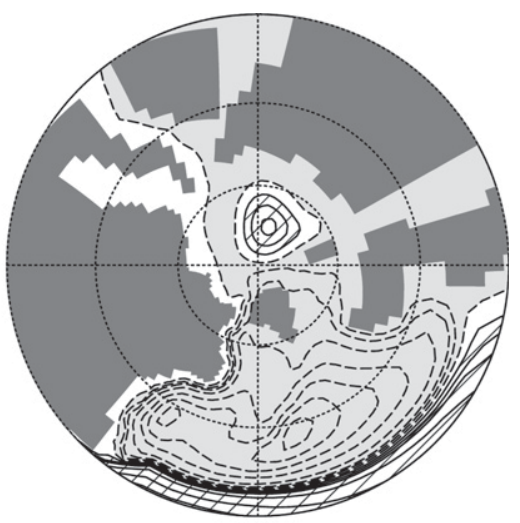

f) $10 x v$, warm - cold

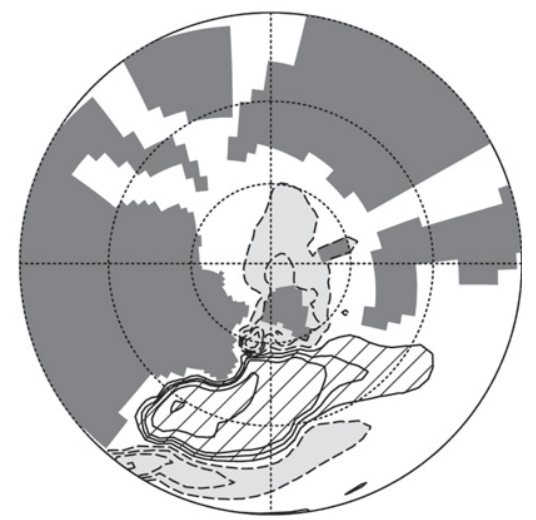

Streamfunction (Sv)

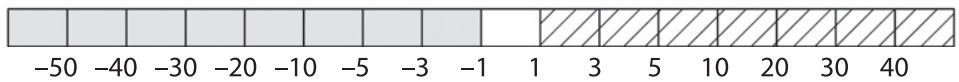

FIG. 10. Mean barotropic streamfunctions (Sv) for (a) 1xv averaged over 1615-25, (b) 10xn averaged over 1090-1110, and (c) 10xv averaged over 900-50. (d)-(f) Differences in the barotropic streamfunction between warm and cold events; (d) 1615-25 minus 1655-65 in 1xn, (e) 1090-1100 minus 960-80 in 10xn, and (f) 900-50 minus 700-50 in 10xv. Hatched shading denote positive values (anticyclonic flow) and light gray denotes negative values (cyclonic flow).

steepened topographic gradient strengthens and maintains geostrophic exchange between the northern Pacific and Arctic (as indicated by the decrease in barotropic streamfunction at $\sim 75^{\circ} \mathrm{N}$ in Figs. 10e,f), promoting continued mass, heat, and salinity transport into the Arctic Ocean.

Arctic warming is amplified and expanded by enhanced ocean-air heat exchange. As described above, geostrophic flow enhances heat transport into the Arctic. The advection of anomalous saline water into the Arctic breaks the polar ocean stratification, intensifying convective mixing to depths of more than $700 \mathrm{~m}$ along the southern margin of the Siberian Peninsula (not shown) and contributing to sensible heat release from the ocean surface. As in the $1 \mathrm{xv}$ experiment, surface heating reduces lower-troposphere static stability, destroying the low-level inversion at which stratus clouds form and enhancing shallow atmospheric convection. In the absence of sea ice, the reduction in low clouds acts as a positive feedback on the ocean to further amplify surface warming (Table 2). During warm events, low cloud amounts decrease by more than 0.10 in the vicinity of the Siberian Peninsula (Figs. 11b,c) increasing cloud radiative forcing (CRF) by up to $10 \mathrm{~W} \mathrm{~m}^{-2}$ (Figs. 11e,f). CRF serves as a strong instantaneous $($ lag $=0)$ positive feedback on Arctic surface air temperature and is characterized by peak-to-peak amplitudes of more than 0.06 PW (Figs. 12b,c), about one-half of high-latitude OHT amplitudes. Surface heating also causes more vigorous atmospheric convection, as evidenced by local increases of up to $1 \mathrm{~mm} \mathrm{day}^{-1}$ in convective precipitation (not shown). 
a) $1 \times v$, warm - cold

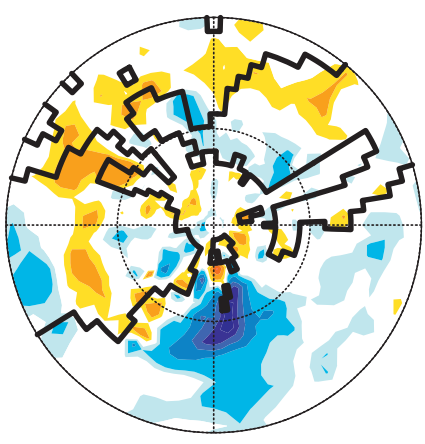

d) $1 \times x$, warm - cold

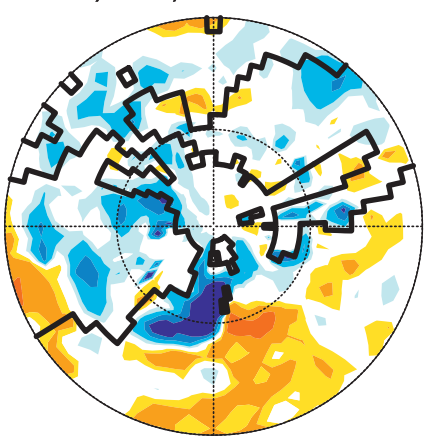

b) 10xn, warm - cold

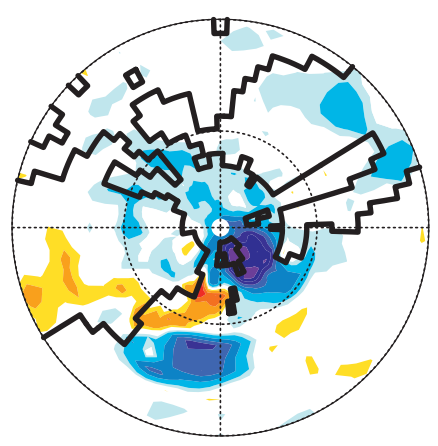

e) 10xn, warm - cold

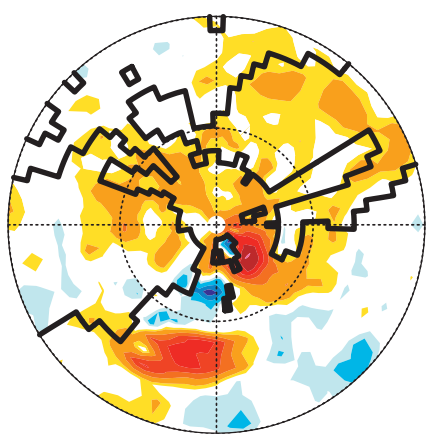

c) $10 x v$, warm - cold
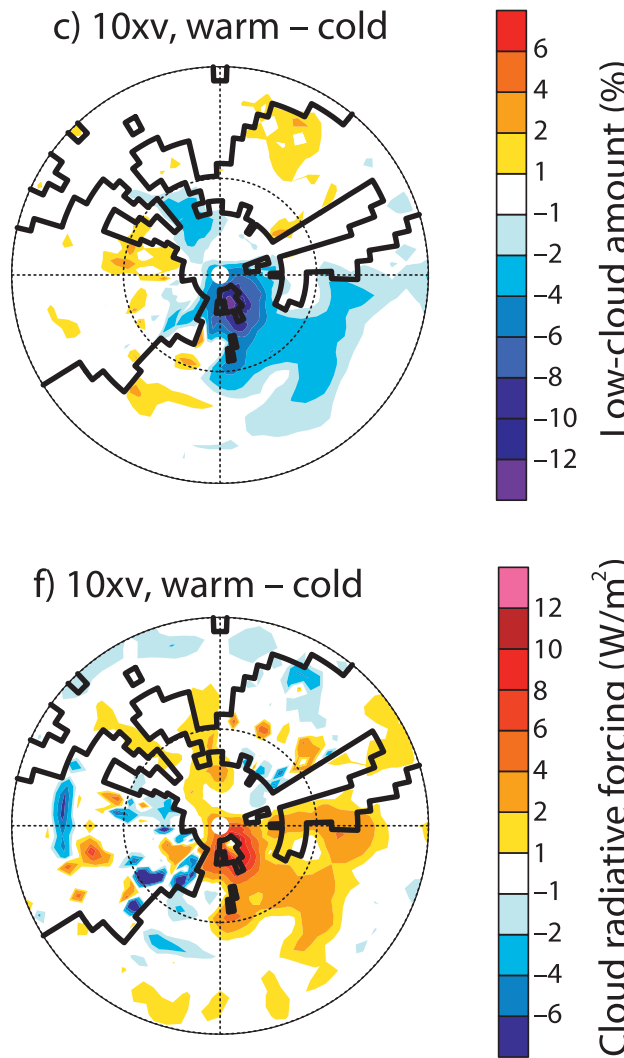

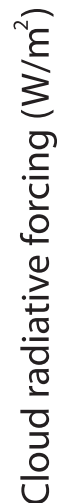

FIG. 11. Northern Hemisphere mean-annual low cloud amount (\%) and cloud radiative forcing $\left(\mathrm{W} \mathrm{m}^{-2}\right)$ differences between warm and cold events simulated in the 1xv, 10xn, and 10xv simulations. Differences are for 1xv (a) 1615-25 and (d) 1655-65; 10xn (b) 1090-1110 and (e) 960-80; and 10xv (c) 900-50 and (f) 700-50. Compare with Fig. 3 to see timing and magnitude of events. In the presence of sea ice, reduction in low clouds in (a) over the northern North Pacific has a negative radiative forcing in (d). In the 10x cases, destruction of low clouds in (b),(c) leads to positive radiative forcing in (e),(f). Continental shorelines are indicated by thick black lines.

\section{f. Cretaceous Arctic variability under high (10 and 16 times) $\mathrm{CO}_{2}$ levels}

In comparison to the $1 \mathrm{x}$ experiments, $10 \mathrm{xn}$, and $10 \mathrm{xv}$ prewarming phase of the $10 \mathrm{xv}$ experiments, multidecadal Arctic SST variability is muted in the postwarming phase of the $10 \mathrm{xv}$ and the $16 \mathrm{xv}$ experiments. In both cases, the amplitudes of peak-to-peak Arctic SST variations are less than $0.6^{\circ} \mathrm{C}$ (Figs. 3c,d) and possess a red noise spectrum. Although there is a statistically significant relationship between Arctic SST and highlatitude OHT in the 10xv postwarming phase, the correlation is weak $(r=-0.4)$ and negative, and OHT lags SST by $\sim 10 \mathrm{yr}$. Salinity and OHT are not significantly correlated. In the $16 \mathrm{xv}$ case, there is no significant correlation between Arctic SST and high-latitude OHT or salinity and OHT. As in the 10xn and prewarming 10xv experiments, Arctic SSTs, low-cloud amounts and cloud radiative forcing are significantly correlated (Table 2 ).

These results suggest that the damping of Arctic climate variability in a warmer climate is related to changes in upper-ocean processes. In confirmation, upper-ocean
$(100 \mathrm{~m})$ static stability is greater in the postwarming $10 \mathrm{xv}$ and $16 \mathrm{xv}$ experiments (Fig. 15) due to warming and, in the $16 \mathrm{xv}$ case, an enhanced surface moisture flux than in the other experiments. As discussed in section $3 \mathrm{~d}$, Arctic temperature variability in the 10xn and prewarming phase of the $10 \mathrm{xv}$ experiments is ultimately sustained through surface heat exchange between the ocean and atmosphere. Enhanced static stability reduces this exchange through decreased upper-ocean mixing and leads to a reduction in surface temperature variability.

\section{g. Meridional overturning and Arctic climate variability}

The relationship between NMOC and Arctic climate variability varies between experiments. In the $1 \mathrm{xv}$ and 10xn experiments, NMOC lags high-latitude OHT by $\sim 5 \mathrm{yr}$ and increases by more than $6 \mathrm{~Sv}$ during warm events (Table 2; Figs. 8a,b). The intensification of NMOC in these experiments is a response to increasing North Pacific subpolar potential density through enhanced upperocean salinity transport. Densification of the northern 

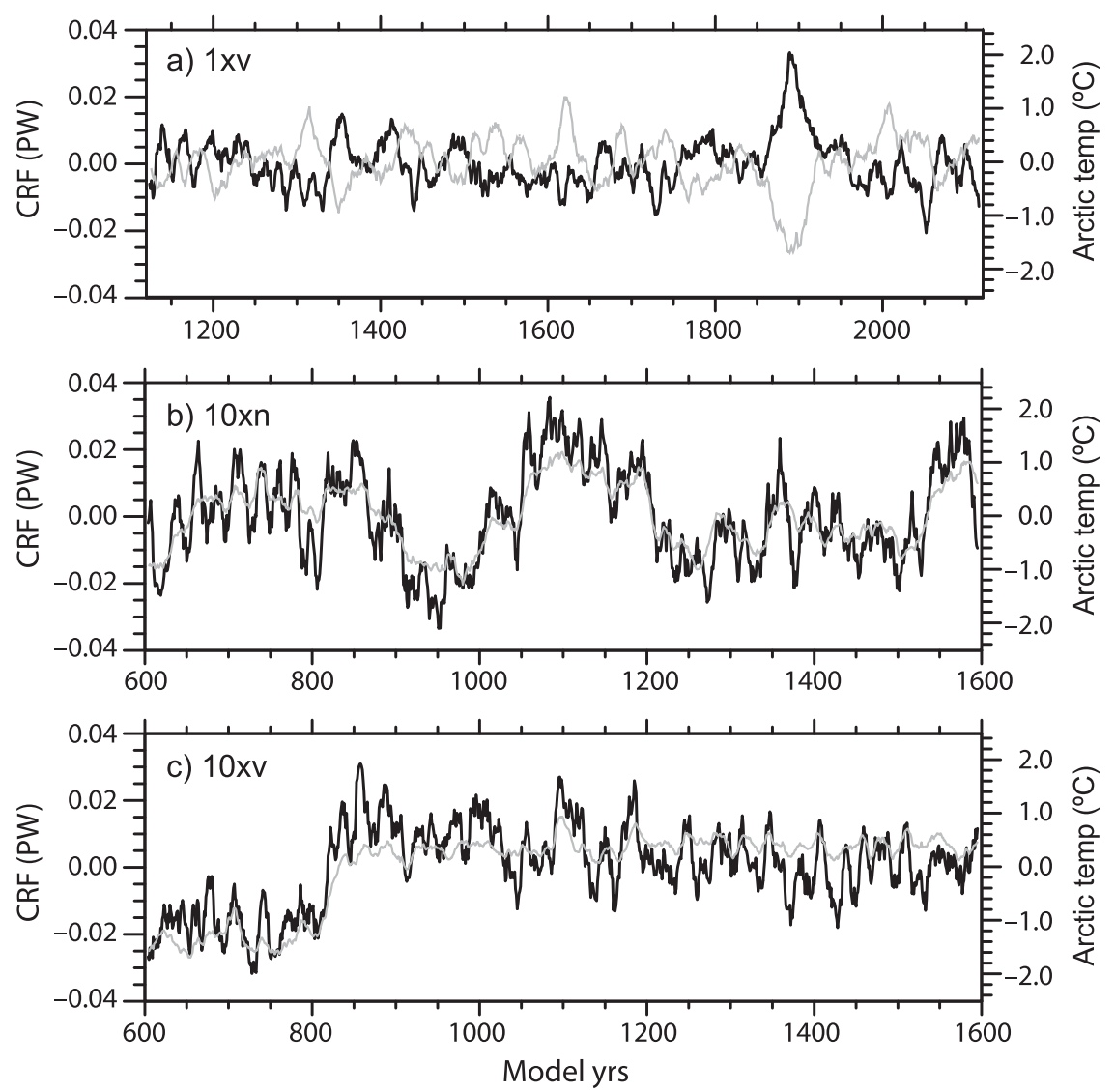

FIG. 12. Time series of cloud radiative forcing (CRF) anomalies (PW; black line) and surface temperature anomalies $\left({ }^{\circ} \mathrm{C}\right.$; gray line) over the Arctic region $\left(70^{\circ}-90^{\circ} \mathrm{N}\right)$ for (a) $1 \mathrm{xv}$, (b) $10 \mathrm{xn}$, and (c) $10 \mathrm{xv}$ experiments.

North Pacific increases the meridional density gradient, which, in agreement with theory (e.g., Park 1999) and previous modeling studies (e.g., Hughes and Weaver 1994), stimulates stronger meridional overturning. In support of this conclusion, NMOC and potential density (averaged over $65^{\circ}-85^{\circ} \mathrm{N}, 150^{\circ}-250^{\circ} \mathrm{E}$ ) share a positive linear relationship when potential density leads by $\sim 9 \mathrm{yr}$ in the 10xn experiment (Fig. 16a). Notably, the linear relationship between NMOC and potential density (and salinity, not shown) is negative when NMOC leads by $\sim 10$ yr (Fig. 16a). This result suggests that while NMOC does not play a role in the onset of warm events it may contribute to the decay of warm events through transport of lower-salinity, lower-density seawater into the Arctic region. Regression coefficients for subpolar barotropic streamfunction and NMOC are consistent with and support these conclusions: when the subpolar streamfunction leads, the linear relationship between streamfunction and NMOC is negative, indicating that times of enhanced mass transport into the Arctic intensify the NMOC (not shown). Conversely, when NMOC leads, the relationship is positive, indicating that enhanced NMOC leads to weakening of the barotropic streamfunction.

The link between NMOC and Arctic climate variability is less clear in the $16 x v$ experiment and the prewarming phase of the $10 \mathrm{xv}$ experiment. Although our correlation analysis produces significant relationships between NMOC and both surface air temperature and potential density, the number of antiphased correlation peaks suggests that these relationships are not robust. The absence of a physical link is not surprising; in both the $16 \mathrm{xv}$ experiment and in the early part of the $10 \mathrm{xv}$ experiment, NMOC and NMOC variability are weak, particularly in the northern North Pacific region.

The abrupt warming event in the $10 \mathrm{xv}$ experiment alters the relationship between NMOC and Arctic climate variability. After the warming event, NMOC gradually intensifies from a maximum of $\sim 12$ to $\sim 18 \mathrm{~Sv}$ and expands poleward, and NMOC variability increases (Figs. 2c,e and 8c). Once vigorous NMOC is established in the North Pacific subpolar region, 
a) $10 \times n$

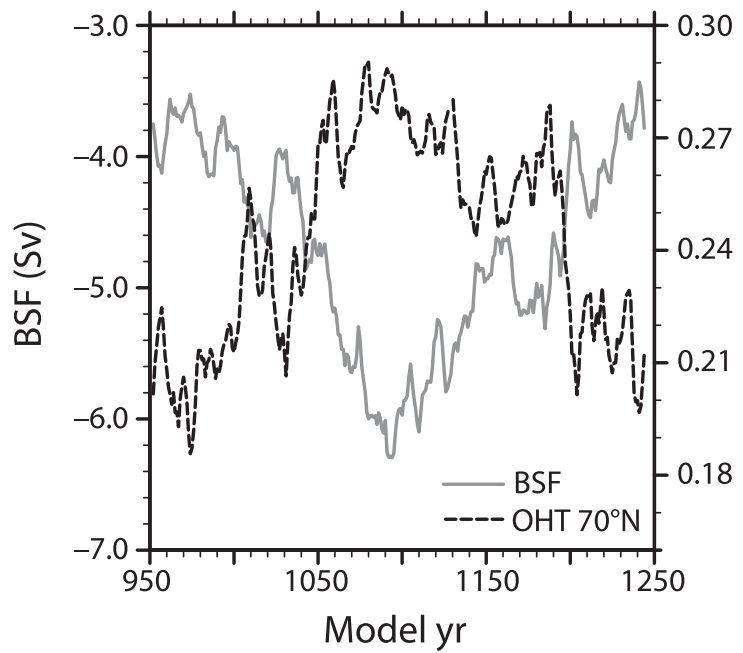

b) $10 x v$

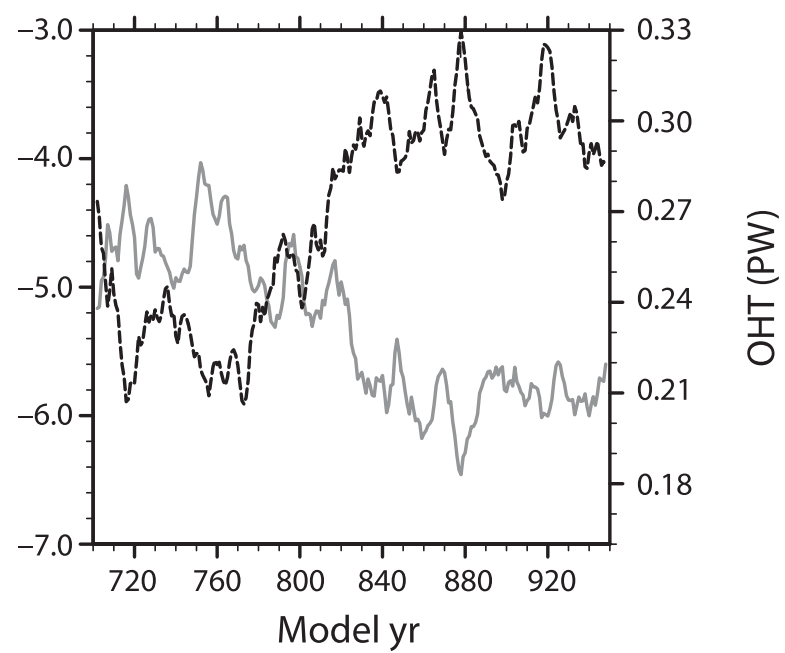

FIG. 13. Time series of the barotropic streamfunction (Sv) in the Bering Strait (solid gray line) and the ocean heat transport (PW) at $70^{\circ} \mathrm{N}$ (dashed black line) for (a) 10xn between 950-1250 and (b) 10xv between 700-950. Note that negative barotropic streamfunction indicates counterclockwise flow.

lead-lag relationships between NMOC and high-latitude potential density similar to those in the $1 \mathrm{xv}$ and $10 \mathrm{xn}$ cases are established. It is notable that the regression coefficients between NMOC and potential density are larger by more than a factor of 10 in the $10 x v$ case than in the 10xn case (Fig. 16b), indicating that greater density anomalies are required to produce equivalent NMOC changes. This difference is consistent with the

\section{a) 10xn, warm - cold}

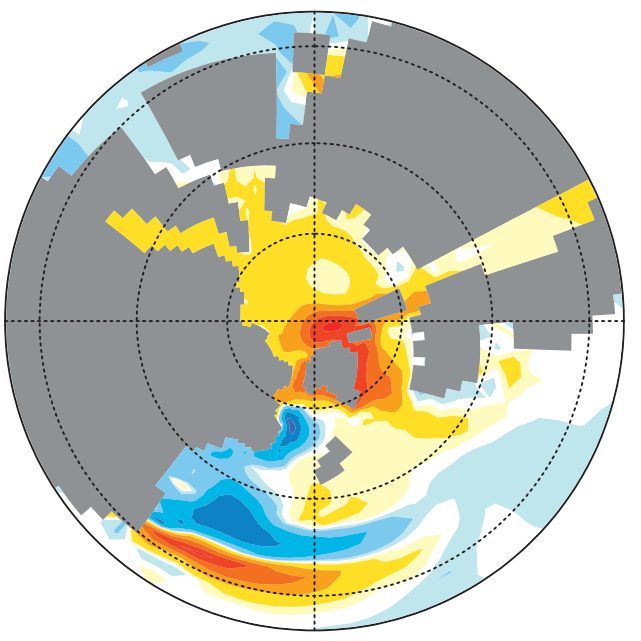

b) $10 x v$, warm - cold

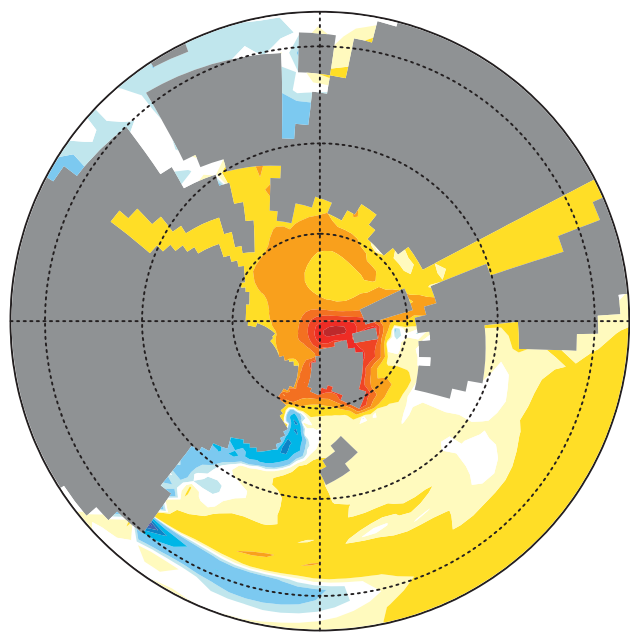

50-m salinity (psu)

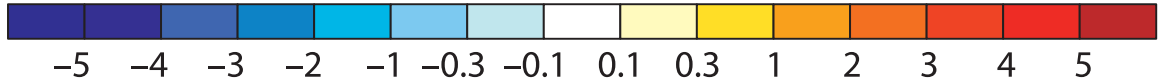

FIG. 14. Northern Hemisphere mean 50-m sea surface salinity (psu) difference between warm and cold intervals in the 10xn and 10xv simulations. Salinity differences are shown for (a) 10xn between 1090-1110 and 960-80 and (b) 10xv between 900-50 and 700-50. Compare with Figs. 3b,c to see timing and magnitude of Arctic events. Continents are indicated by dark gray shading. 


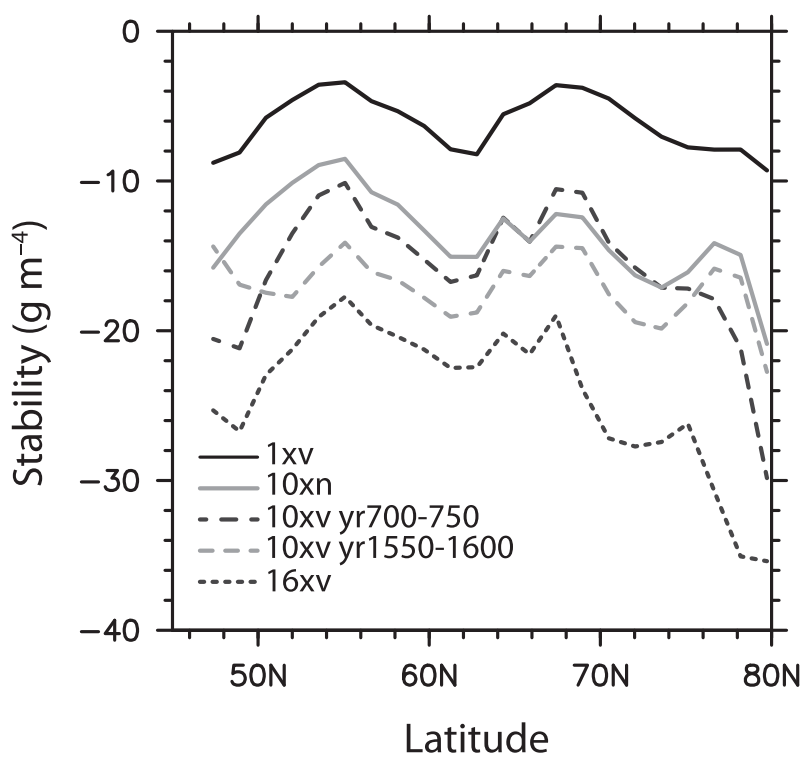

FIG. 15. Zonally averaged static stability $\left(\mathrm{g} \mathrm{m}^{-4}\right)$ in the upper $100 \mathrm{~m}$ of the North Pacific and Arctic Oceans. Lower (more negative) stability signifies greater ocean stratification.

greater upper-ocean stability in the $10 x v$ case (Fig. 15) and accounts for the absence of warming events after year 850 .

The role of NMOC in surface temperature variability in the $10 \mathrm{xn}$ and $10 \mathrm{xv}$ experiments is revealed in the distinct timing of surface temperature anomalies (Fig. 6). In both simulations, surface temperatures increase by several degrees in the Arctic and in the midlatitudes of

the western North Pacific during warm episodes (Figs. 6a,c,d). In the 10xn experiment, because of the fast, large response of NMOC and midlatitude OHT to potential density anomalies in the Arctic region, the warming (and cooling) of these two regions is nearly simultaneous (Figs. 6a,b). In the 10xv experiment, NMOC and NMOC variability are initially weak (Figs. 2e and $8 c$ ) and have little influence on surface temperatures. As a result, Arctic warming through upper-ocean processes occurs independently of and precedes midlatitude warming by several centuries. Warming of the western Pacific occurs slowly over a period of more than $400 \mathrm{yr}$ as NMOC steadily intensifies (Fig. 8c). The distinct timing of Arctic and midlatitude warming provides confirmation that two different processes are responsible for temperature variability in these regions.

\section{Discussion}

\section{a. Influence of mean climate state on Arctic climate variability}

The most intriguing conclusion of this study is that the mean state has a significant influence on high-latitude climate variability. Under low $\mathrm{CO}_{2}$ levels and in the presence of substantial high-latitude sea ice, the frequency of surface temperature variability is higher (decadal to multidecadal time scales) and tightly coupled to sea ice variability in a poorly stratified highlatitude ocean (Fig. 3a). In this case, sea ice variability is likely driven by internal atmospheric variability (e.g.,

a) $10 \times n$

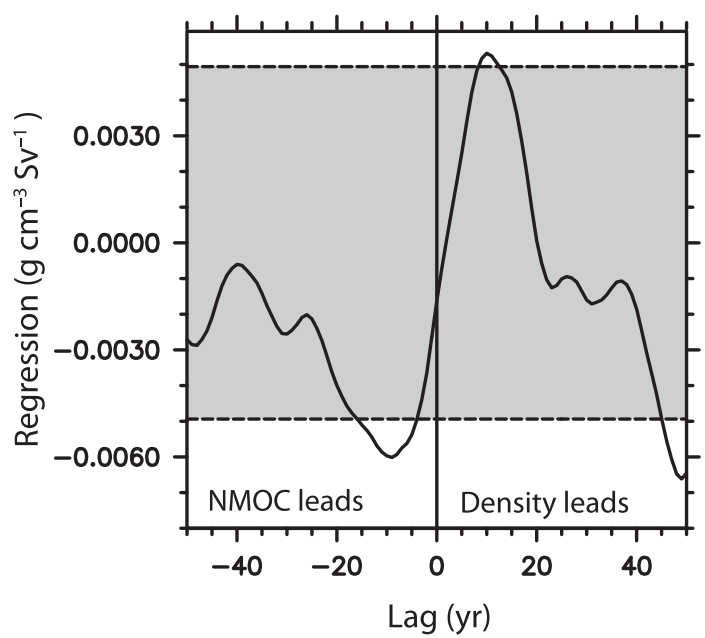

b) $10 x v$

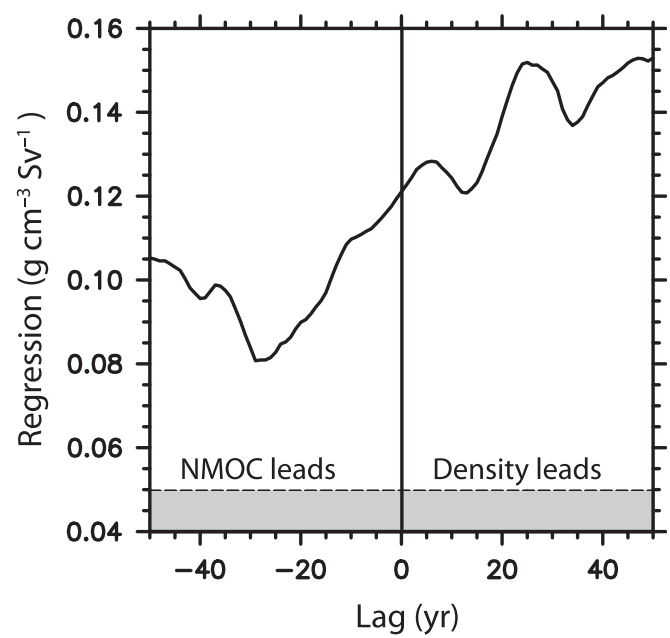

FIG. 16. Regression coefficients between NMOC and potential density (PD) anomalies for years (a) 950-1250 in $10 x n$ and (b) 700-950 in the 10xv experiment. The gray shaded area indicates region below the $99 \%$ significance level. Negative lag means MOC leads PD. 


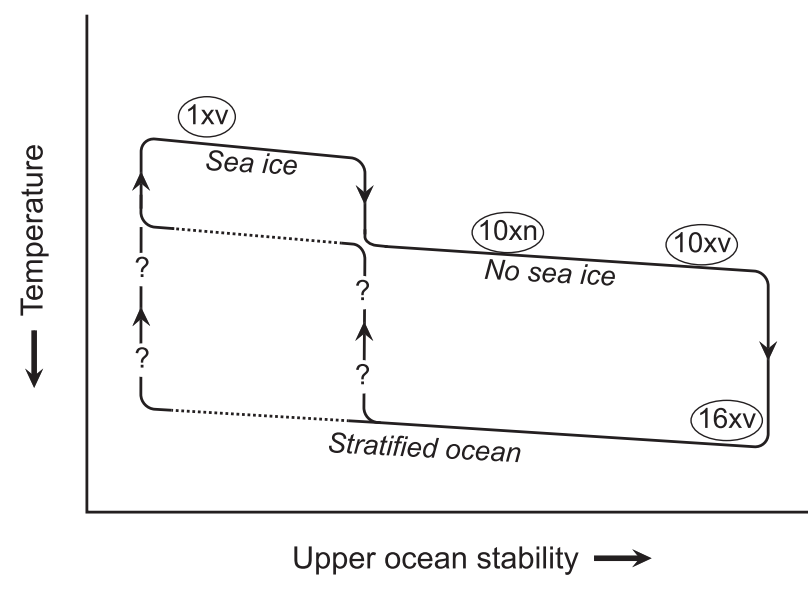

FIG. 17. Arctic climate stability diagram. Three steady states are shown for the Arctic climate, a cold branch with high-frequency variability, a cool branch with low-frequency variability, and a warm branch with damped variability. Transition points are shown by vertical lines; arrows indicate the direction of the transition. The locations of the Cretaceous simulations (1xv, 10xn, 10xv, and 16xv) are labeled on the diagram. See the text for further discussion.

Arctic oscillation) and amplified by changes in ocean heat transport, as in the modern climate (e.g., Dickson et al. 2000). At higher $\mathrm{CO}_{2}$ levels and in the absence of substantial sea ice, the frequency is lower and principally linked to upper-ocean stability (Figs. 3b-d). In these simulations, upper-ocean mass transport and salinity advection force Arctic surface temperature variability. The high $\mathrm{CO}_{2}$ simulations (10xn, 10xv, and 16xv) demonstrate that extreme sensitivity of the Arctic variability to high-latitude freshwater forcing and the background state in a warm world. Both the inclusion of vegetation (through coupling with DVGM) and the increase in atmospheric $\mathrm{CO}_{2}$ increase Northern Hemisphere highlatitude surface temperatures and precipitation (Zhou et al. 2012), and enhance ocean stratification, leading to drastic differences in Arctic variability.

Our simulations indicate the existence of hysteresis in the Arctic climate, which are dependent on high-latitude temperature through the presence of sea ice and upperocean stability (Fig. 17). From this perspective, the 1xv, $10 \mathrm{xn}$, and 16xv simulations represent stable branches characterized by (i) a cold Arctic climate with sea ice and high-frequency, high-magnitude variability; (ii) a cool Arctic climate and low-frequency, high-magnitude variability; and (iii) a warm Arctic climate with damped variability (Fig. 17). The 10xv simulation lays on or near the transition from a cool state that is susceptible to variability to a warmer one that is not. The nonlinear transitions between branches represent points at which near-surface density anomalies (e.g., through salinity advection) become capable (in a cooling climate) or incapable (in a warming climate) of destabilizing the upper-ocean stratification. The location of these transition points is undoubtedly dependent on geography and the particulars of high-latitude freshwater forcing, and is certainly model and possibly resolution dependent to some degree. From the limited number of simulations reported here, it is impossible to know whether additional steady states exist (indicated by dashed lines in Fig. 17) and precisely where the transitions between states occur (indicated by question marks in Fig. 17). These details, and confirmation of the hysteresis behavior under modern geography, will need to be pursued in the future.

\section{b. Implications for Cretaceous polar climates}

The mid-Cretaceous was one of the warmest periods in the Phanerozoic, and warmest in the last $100 \mathrm{Ma}$. Low-latitude sea surface temperatures are estimated to have been $\sim 33^{\circ} \mathrm{C}\left( \pm 3^{\circ} \mathrm{C}\right)$ (Norris et al. 2002; Wilson et al. 2002; Schouten et al. 2003), approximately $6^{\circ} \mathrm{C}$ warmer than present. High-latitude continents were warm with MATs between $\sim 8^{\circ}$ and $14^{\circ} \mathrm{C}$ (Spicer and Herman 2010), and Arctic surface water temperatures were at least seasonally greater than $\sim 15^{\circ} \mathrm{C}$ and ice free (Davies et al. 2009). While Cretaceous warmth is widely attributed to elevated atmospheric $\mathrm{CO}_{2}$, the extreme polar warm and reduced meridional temperature gradient inferred from proxy data defy simple explanation (Poulsen 2004). A number of solutions have been proposed to solve this problem including enhancement of poleward ocean heat transport (e.g., Covey and Thompson 1989) and radiative warming by high-latitude clouds (Sloan and Pollard 1998; Abbot and Tziperman 2008; Kump and Pollard 2008). These explanations, while compelling, have been viewed somewhat skeptically either because they require special conditions (e.g., enhanced tropospheric methane oxidation, reduction in cloud condensation nuclei concentration) for which geologic evidence does not exist or call on physical mechanisms (enhanced ocean heat transport, polar atmospheric convection) that have not been substantiated. Though polar temperatures in our $10 \mathrm{xv}$ simulation are still cooler than the extreme estimates from proxy data, this simulation demonstrates a polar warming mechanism (of $2^{\circ} \mathrm{C}$ and locally $>5^{\circ} \mathrm{C}$ ) involving both regionally enhanced ocean heat transport to the Arctic and increased cloud radiative forcing through enhanced low-level convection and a reduction in low-level clouds that does not require any modifications to existing model physics. The warming, which persists through the remainder of the simulation $(>800 \mathrm{yr})$, is sustained through geostrophic adjustment of the subpolar upperocean circulation. 
The fact that a relatively small reduction $(\sim 0.10$; expressed as \% in Figs. 11a-c) in low cloud fractions is responsible for about one-half of the Arctic warming in the 10x simulations demonstrates the importance of low clouds in cooling polar regions. In the high $\mathrm{CO}_{2}$ Cretaceous simulations, total cloud radiative forcing is approximately $-17 \mathrm{~W} \mathrm{~m}^{-2}$, more than 3 times that in the $1 \mathrm{xv}$ simulation $\left(-5.4 \mathrm{~W} \mathrm{~m}^{-2}\right)$. This large difference in cloud radiative forcing is due to the split role of low clouds, which warm high-albedo surfaces and cool lowalbedo surfaces (Pierrehumbert 2002). In CCSM3, as in other GCMs (Vavrus et al. 2009), the fraction of low clouds in the modern Arctic is overestimated by up to 0.5 during winter and 0.1 during summer (Vavrus and Waliser 2008), leading to a significant warm bias in the region. Since the low cloud bias is greatest under cold winter conditions and our high- $\mathrm{CO}_{2}$ Cretaceous simulations are considerably warmer than modern, the lowcloud bias might be significantly reduced. This does not appear to be the case; Arctic low-cloud amounts are $0.62-0.65$ in winter and $0.74-0.76$ in summer in the $10 \mathrm{xn}$, $10 \mathrm{xv}$, and $16 \mathrm{xv}$ simulations, essentially the same as in the modern CCSM3 simulation (e.g., see Fig. 6 in Vavrus and Waliser 2008). If Arctic low clouds were overestimated, it would introduce a substantial cool bias and could be a significant reason for the underestimate of high-latitude temperatures.

\section{c. Meridional overturning circulation in a warm world}

The nature of deep-ocean circulation and meridional overturning in the Cretaceous is uncertain and has been a topic of longstanding debate. The occurrence of oceanic anoxic events, intermittent episodes (lasting $<500 \mathrm{kyr}$ ) of widespread organic-rich black shale deposition during which regions of the subsurface ocean were anoxic or suboxic (OAEs), has been interpreted as evidence that circulation was sluggish with slow turnover rates (and thus low oxygenation rates) as a result of reduced Cretaceous thermal gradients (e.g., Schlanger and Jenkyns 1976; Bralower and Thierstein 1984). Cretaceous coupled ocean-atmosphere simulations, however, predict MOC fluxes similar or greater than modern simulations (e.g., Otto-Bliesner et al. 2002; Brady et al. 1998). In our CCSM3 Cretaceous simulations, to the degree that meridional density gradients are weakened in the ocean, maximum MOC fluxes generally decrease with $\mathrm{CO}_{2}$ and a reduced equator-to-pole temperature gradient (Fig. 2). However, our 10x experiments demonstrate that freshwater forcing through land surface characteristics (in the 10xn simulation) and salinity advection through the subpolar gyre (in the 10xv simulation) can enhance the meridional density gradient in favor of more vigorous MOC, and that multiple overturning states with relatively strong and weak overturning may exist under high atmospheric $\mathrm{CO}_{2}$.

Most coupled ocean-atmosphere models for the present day show that the Atlantic meridional overturning circulation weakens as $\mathrm{CO}_{2}$ levels increase because of warming and freshening of the high-latitude North Atlantic Ocean (Gregory 2005). Our 10xv simulation demonstrates an intrinsic mechanism that could counteract this freshening. In particular, enhanced poleward flow of warmer, saline water from the North Pacific into the Arctic modifies the upper-ocean density structure, weakening the subpolar gyre and enhancing geostrophic transport and mass exchange with the Arctic. These structural changes are self-sustaining and lead to upperocean densification and slow intensification of the MOC (Fig. 8c). There is observational evidence that similar processes are happening in the modern North Atlantic. Hátún et al. (2005) report a salinity increase in the Atlantic inflow to the Nordic seas and the Arctic Ocean, which they also attribute to subpolar gyre dynamics and enhanced mass transport into the Arctic.

\section{Conclusions}

Paleoclimate simulations of the mid-Cretaceous with preindustrial $\mathrm{CO}_{2}$ levels exhibit unforced multidecadal surface temperature variability in the Arctic that is similar in character to that observed in the modern simulation despite differences in geography. The frequency of Arctic surface temperature decreases in simulations with higher $\mathrm{CO}_{2}$ (10 and 16 times preindustrial levels.), a response that is linked to the disappearance of widespread Arctic sea ice and an increase in stratification of the upper ocean. At 10 times preindustrial $\mathrm{CO}_{2}$ values, low-frequency surface temperature variability occurs on centennial and longer time scales. Arctic variability is tied to mass transport and ocean heat transport into the Arctic and is amplified by changes in cloud radiative forcing associated with polar low cloud amounts. At even higher $\mathrm{CO}_{2}$ values, the upper ocean becomes statically stable and exhibits little surface temperature variability.

Paleoclimate simulations with 1 and 10 times preindustrial $\mathrm{CO}_{2}$ values exhibit a link between Arctic climate and meridional overturning circulation, with the Northern Hemisphere meridional overturning lagging the Arctic climate and increasing during warm periods. Though meridional overturning circulation does not play a primary role in development of warm events, it may contribute to dissipation of warm events (in our 10xn simulation) through advection of low salinity water into the North Pacific Ocean. Under warmer high-latitude 
conditions and greater ocean stratification (our 10xv simulation), the ocean exhibits multiple steady states characterized by weak (strong) meridional overturning and cool (warm) Arctic temperatures.

This study has potential implications for past and future climates. Our simulations demonstrate a mechanism for polar warming involving both increases in ocean heat transport and cloud radiative forcing (without any modification to CCSM3 physics). This mechanism ameliorates the long-standing discrepancy between Cretaceous climate models and proxy data. Finally, our results indicate that past Arctic climate variability was likely much different than the modern climate and raise the possibility that future Arctic climate under higher $\mathrm{CO}_{2}$ levels will be so as well.

Acknowledgments. This study was financially supported by a grant (0433440) from the National Science Foundations' Paleoclimate Program to C. Poulsen and a Barbour Scholarship from the University of Michigan to J. Zhou. We thank E. Brady, B. Briegleb, C. Shields, and N. Rosenbloom for assistance with CCSM3, and three reviewers for their constructive comments. The CCSM3 simulations were run at the National Center for Atmospheric Research (NCAR).

\section{REFERENCES}

Abbot, D. S., and E. Tziperman, 2008: A high-latitude convective cloud feedback and equable climates. Quart. J. Roy. Meteor. Soc., 134, 165-185.

Barron, E. J., 1983: A warm, equable Cretaceous: The nature of the problem. Earth Sci. Rev., 19, 305-338.

_ , and W. H. Peterson, 1990: Mid-Cretaceous ocean circulation: Results from model sensitivity studies. Paleoceanography, 5, 319-337, doi:10.1029/PA005i003p00319.

Bengtsson, L., V. Semenov, and O. Johannessen, 2004: The early twentieth-century warming in the Arctic-A possible mechanism. J. Climate, 17, 4045-4057.

Bice, K. L., and R. D. Norris, 2002: Possible atmospheric $\mathrm{CO}_{2}$ extremes of the Middle Cretaceous (late Albian-Turonian). Paleoceanography, 17, 22-1, doi:10.1029/2002PA000778.

Brady, E. C., R. M. Deconto, and S. L. Thompson, 1998: Deep water formation and poleward ocean heat transport in the warm climate extreme of the Cretaceous (80 Ma). Geophys. Res. Lett., 25, 4205-4208.

Bralower, T. J., and H. R. Thierstein, 1984: Low productivity and slow deep-water circulation in mid-Cretaceous oceans. Geo$\log y, \mathbf{1 2}$, 614-618.

Briegleb, B. P., C. M. Bitz, E. C. Hunke, W. H. Lipscomb, M. M. Holland, and J. L. Schramm, 2004: Scientific description of the sea ice component in the Community Climate System Model, version 3. NCAR Tech. Rep. NCAR/TN-463+STR, Boulder, $\mathrm{CO}, 78 \mathrm{pp}$.

Bryan, F. O., G. Danabasoglu, N. Nakashiki, Y. Yoshida, D.-H. Kim, J. Tsutsui, and S. C. Doney, 2006: Response of the North Atlantic thermohaline circulation and ventilation to increasing carbon dioxide in CCSM3. J. Climate, 19, 2382-2397.
Clement, A. C., M. A. Cane, and R. Seager, 2001: An orbitally driven tropical source for abrupt climate change. J. Climate, 14, 2369-2375.

Collins, W. D., and Coauthors, 2006: The Community Climate System Model version 3 (CCSM3). J. Climate, 19, 21222143.

Comiso, J. C., 2002: A rapidly declining perennial sea ice cover in the Arctic. Geophys. Res. Lett., 29, 1956, doi:10.1029/2002GL015650.

Covey, C., and S. L. Thompson, 1989: Testing the effects of ocean heat transport on climate. Palaeogeogr. Palaeoclimatol. Palaeoecol., 75, 331-341.

Davies, A., A. Kemp, and J. Pike, 2009: Late Cretaceous seasonal ocean variability from the Arctic. Nature, 460, 254-258.

Delworth, T., S. Manabe, and R. J. Stouffer, 1993: Interdecadal variations of the thermohaline circulation in a coupled oceanatmosphere model. J. Climate, 6, 1993-2011.

Dickinson, R. E., K. W. Oleson, G. Bonan, F. Hoffman, P. Thornton, M. Vertenstein, Z.-L. Yang, and X. Zeng, 2006: The Community Land Model and its climate statistics as a component of the Community Climate System Model. J. Climate, 19, 2302-2324.

Dickson, R. R., and Coauthors, 2000: The Arctic Ocean response to the North Atlantic Oscillation. J. Climate, 13, 2671-2696.

Donnadieu, Y., R. Pierrehumbert, R. Jacob, and F. Fluteau, 2006: Modelling the primary control of paleogeography on Cretaceous climate. Earth Planet. Sci. Lett., 248, 411-422, doi:10.1016/ j.epsl.2006.06.007.

Goosse, H., and M. Holland, 2005: Mechanisms of decadal Arctic climate variability in the Community Climate System Model, version 2 (CCSM2). J. Climate, 18, 3552-3570.

Gough, D. O., 1981: Solar interior structure and luminosity variations. Sol. Phys., 74, 21-34.

Gregory, J. M., 2005: A model intercomparison of changes in the Atlantic thermohaline circulation in response to increasing atmospheric $\mathrm{CO}_{2}$ concentration. Geophys. Res. Lett., 32, L12703, doi:10.1029/2005GL023209.

Hátún, H. H., A. B. A. Sandø, H. H. Drange, B. B. Hansen, and H. H. Valdimarsson, 2005: Influence of the Atlantic subpolar gyre on the thermohaline circulation. Science, 309, 1841-1844, doi:10.1126/science.1114777.

Hughes, T. M. C., and A. J. Weaver, 1994: Multiple equilibria of an asymmetric two-basin ocean model. J. Phys. Oceanogr., 24, 619-637.

Iba, Y., J. Mutterlose, K. Tanabe, S.-I. Sano, A. Misaki, and K. Terabe, 2011: Belemnite extinction and the origin of modern cephalopods 35 m.y. prior to the Cretaceous-Paleogene event. Geology, 39, 483-486, doi:10.1130/G31724.1.

Jenkyns, H., A. Forster, S. Schouten, and J. Damste, 2004: High temperatures in the Late Cretaceous Arctic Ocean. Nature, 432, 888-892, doi:10.1038/nature03143.

Johannessen, O., and Coauthors, 2004: Arctic climate change: Observed and modelled temperature and sea-ice variability. Tellus, 56A, 328-341.

Jungclaus, J. H., and T. Koenigk, 2010: Low-frequency variability of the Arctic climate: The role of oceanic and atmospheric heat transport variations. Climate Dyn., 34, 265-279, doi:10.1007/ s00382-009-0569-9.

Kiehl, J. T., and C. A. Shields, 2005: Climate simulation of the latest Permian: Implications for mass extinction. Geology, 33, 757760, doi:10.1130/G21654.1.

Koutavas, A., and S. Joanides, 2012: El Niño-Southern Oscillation extrema in the Holocene and Last Glacial Maximum. Paleoceanography, 27, PA4208, doi:10.1029/2012PA002378. 
Kump, L. R., and D. Pollard, 2008: Amplification of Cretaceous warmth by biological cloud feedbacks. Science, 320, 195-195, doi:10.1126/science.1153883.

Larson, R. L., 1991: Latest pulse of Earth: Evidence for a midCretaceous superplume. Geology, 19, 547-550.

Lee, T., and M. J. McPhaden, 2010: Increasing intensity of El Niño in the central-equatorial Pacific. Geophys. Res. Lett., 37, L14603, doi:10.1029/2010GL044007.

Levis, S., G. B. Bonan, M. Vertenstein, and K. Oleson, 2004: The Community Land Model's dynamic global vegetation model (CLM-DGVM): Technical description and user's guide. NCAR Tech. Note NCAR/TN-459+IA, 50 pp.

Norris, R., K. Bice, E. Magno, and P. Wilson, 2002: Jiggling the tropical thermostat in the Cretaceous hothouse. Geology, 30, 299-302.

Otto-Bliesner, B. L., E. C. Brady, and C. Shields, 2002: Late Cretaceous ocean: Coupled simulations with the National Center for Atmospheric Research Climate System Model. J. Geophys. Res., 107 (D2), doi:10.1029/2001JD000821.

_ - _ - G. Clauzet, R. Tomas, S. Levis, and Z. Kothavala, 2006a: Last Glacial Maximum and Holocene climate in CCSM3. J. Climate, 19, 2526-2544.

—, R. Tomas, E. Brady, C. Ammann, Z. Kothavala, and G. Clauzet, 2006b: Climate sensitivity of moderate- and low-resolution versions of CCSM3 to preindustrial forcings. J. Climate, 19, 2567-2583.

Park, Y.-G., 1999: The stability of thermohaline circulation in a two-box model. J. Phys. Oceanogr., 29, 3101-3110.

Parkinson, C. L., D. J. Cavalieri, P. Gloersen, H. J. Zwally, and J. C. Comiso, 1999: Arctic sea ice extents, areas, and trends, 19781996. J. Geophys. Res., 104 (C9), 20 837-20856.

Pierrehumbert, R., 2002: The hydrologic cycle in deep-time climate problems. Nature, 419, 191-198, doi:10.1038/nature01088.

Polyakov, I. V., and M. A. Johnson, 2000: Arctic decadal and interdecadal variability. Geophys. Res. Lett., 27, 4097-4100.

_ polar amplification of global warming. Geophys. Res. Lett., 29, 1878, doi:10.1029/2001GL011111.

Poulsen, C. J., 2004: A balmy Arctic. Nature, 432, 814-815.

— E. J. Barron, W. H. Peterson, and P. A. Wilson, 1999: A reinterpretation of mid-Cretaceous shallow marine temperatures through model-data comparison. Paleoceanography, 14, 679-697.

, —_, M. A. Arthur, and W. H. Peterson, 2001: Response of the mid-Cretaceous global oceanic circulation to tectonic and $\mathrm{CO}_{2}$ forcings. Paleoceanography, 16, 576-592.

- A. S. Gendaszek, and R. L. Jacob, 2003: Did the rifting of the Atlantic Ocean cause the Cretaceous thermal maximum? Geology, 31, 115-118.

Rigor, I. G., J. M. Wallace, and R. L. Colony, 2002: Response of sea ice to the Arctic Oscillation. J. Climate, 15, 2648-2663.

Sandweiss, D. H., K. A. Maasch, R. L. Burger, J. B. Richardson III, H. B. Rollins, and A. Clement, 2001: Variation in Holocene El Niño frequencies: Climate records and cultural consequences in ancient Peru. Geology, 29, 603-606.

Schlanger, S. O., and H. C. Jenkyns, 1976: Cretaceous oceanic anoxic events: Causes and consequences. Geol. Mijnbouw, $\mathbf{5 5}$, 179-184.

— - , and I. Premoli-Silva, 1981: Volcanism and vertical tectonics in the Pacific basin related to global Cretaceous transgressions. Earth Planet. Sci. Lett., 52, 435-449.

Schouten, S., E. C. Hopmans, A. Forster, Y. van Breugel, M. M. Kuypers, and J. S. S. Damsté, 2003: Extremely high sea-surface temperatures at low latitudes during the middle Cretaceous as revealed by archaeal membrane lipids. Geology, 31, 10691072 .

Scotese, C. R., 2001: Times of global plate tectonic reorganization and their causes. Extended Abstracts, Earth System Processes, Edinburgh, Scotland, Geological Society of London and Geological Society of America. [Available online at https://gsa confex.com/gsa/2001ESP/finalprogram/abstract_7969.htm.]

Sloan, L. C., and D. Pollard, 1998: Polar stratospheric clouds: A high latitude warming mechanism in an ancient greenhouse world. Geophys. Res. Lett., 25, 3517-3520.

Smith, R. D., and P. R. Gent, Eds., 2002: Reference manual for the Parallel Ocean Program (POP): Ocean component of the Community Climate System Model (CCSM2.0 and 3.0). Los Alamos National Laboratory Tech. Rep. LAUR-02-2484, $75 \mathrm{pp}$.

Spicer, R. A., and A. B. Herman, 2010: The Late Cretaceous environment of the Arctic: A quantitative reassessment based on plant fossils. Palaeogeogr. Palaeoclimatol. Palaeoecol., 295, 423-442, doi:10.1016/j.palaeo.2010.02.025.

_, A. Ahlberg, A. B. Herman, C.-C. Hofmann, M. Raikevich, P. J. Valdes, and P. J. Markwick, 2008: The Late Cretaceous continental interior of Siberia: A challenge for climate models. Earth Planet. Sci. Lett., 267, 228-235.

Stott, L., C. Poulsen, S. Lund, and R. Thunell, 2002: Super ENSO and global climate oscillations at millennial time scales. Science, 297, 222-226.

Tarduno, J., D. Brinkman, P. Renne, R. Cottrell, H. Scher, and P. Castillo, 1998: Evidence for extreme climatic warmth from Late Cretaceous arctic vertebrates. Science, 282, 22412243.

Timmermann, A., J. Oberhuber, A. Bacher, M. Esch, M. Latif, and E. Roeckner, 1999: Increased El Niño frequency in a climate model forced by future greenhouse warming. Nature, 398, 694-697.

Vavrus, S., and D. Waliser, 2008: An improved parameterization for simulating Arctic cloud amount in the CCSM3 climate model. J. Climate, 21, 5673-5687.

,$- \ldots$, A. Schweiger, and J. Francis, 2009: Simulations of 20th and 21st century Arctic cloud amount in the global climate models assessed in the IPCC AR4. Climate Dyn., 33, 10991115, doi:10.1007/s00382-008-0475-6.

Vinje, T., 2001: Anomalies and trends of sea-ice extent and atmospheric circulation in the Nordic seas during the period 1864-1998. J. Climate, 14, 255-267.

Wilson, P., R. Norris, and M. Cooper, 2002: Testing the Cretaceous greenhouse hypothesis using glassy foraminiferal calcite from the core of the Turonian tropics on Demerara Rise. Geology, 30, 607-610.

Winguth, A., C. Shellito, C. Shields, and C. Winguth, 2010: Climate response at the Paleocene-Eocene Thermal Maximum to greenhouse gas forcing-A model study with CCSM3. J. Climate, 23, 2562-2584.

Yeager, S., C. Shields, W. Large, and J. Hack, 2006: The lowresolution CCSM3. J. Climate, 19, 2545-2566.

Zhou, J., C. J. Poulsen, D. Pollard, and T. S. White, 2008: Simulation of modern and middle Cretaceous marine $\delta^{18} \mathrm{O}$ with an ocean-atmosphere general circulation model. Paleoceanography, 23, PA3223, doi:10.1029/2008PA001596.

— — - N. Rosenbloom, C. Shields, and B. Briegleb, 2012: Vegetation-climate interactions in the warm mid-Cretaceous. Climate Past, 8, 565-576, doi:10.5194/cp-8-565-2012. 